\title{
Lower Cretaceous succession and biostratigraphy near overthrust plane of Silesian Nappe (Ostravice River Channel, Outer Western Carpathians, Czech Republic)
}

\author{
EVA HALÁSOVÁ, ZDENĚK VAŠíčEK, LUBOMÍR JANSA, DANIELA REHÁKOVÁ \& PETR SKUPIEN
}

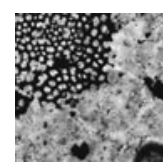

Contact between the Upper Cretaceous rocks of the Subsilesian Nappe and the overthrust Lower Cretaceous rocks of the Silesian Nappe is uniquely exposed at locality Ostravice River Chanell. The deposits of the Silesian Nappe in the zone of overthrust plane that belong to the Hradiště Formation are tectonically affected. The more exact age of the mentioned rocks has never been documented earlier. The most significant stratigraphic data were obtained by the analysis of calcareous nannofossils. The sediments of the Hradiště Formation in the zone of overthrust of the Silesian Nappe belong to two partial tectonic slices. Sediments of slice on the contact between both the Nappes is, according to calcareous nannoplankton, of latest Hauterivian to Early Barremian age. In the area of the rapids, the other slice lying on it is of Late Hauterivian age. Micritic limestones occurring in the Late Hauterivian slice indicate basinal sedimentation above the carbonate dissolution level. Character of intercalated sandstones indicates of its turbiditic origin. Limestone interclasts in layers of gravelly sandstones document the erosion of the Upper Jurassic to early Lower Cretaceous carbonate platform by turbiditic currents. Further up the river, deposits belonging to higher, partial tectonic slices and stratal members of the Silesian Nappe were identified. At the beginning, a small part of the Veřovice Formation of Late Aptian age is exposed. After interruption, a huge outcrop of the Lhoty Formation of Middle and Late Albian age follows and then again the higher part of Hradiště Formation of Early Aptian age. $•$ Key words: Silesian Unit, Lower Cretaceous, thin sections, calcareous nannofossils, dinoflagellates.

HALÁSOVÁ, E., VAŠíčEK, Z., JANSA, L., REHÁKOVÁ, D. \& SKUPIEN, P. 2012. Lower Cretaceous succession and biostratigraphy near overthrust plane of Silesian Nappe (Ostravice River Channel, Outer Western Carpathians, Czech Republic). Bulletin of Geosciences 87(2), 383-406 (10 figures, appendix). Czech Geological Survey, Prague. ISSN 1214-1119. Manuscript received October 11, 2011; accepted in revised form March 1, 2012; published online March 29, 2012; issued March 30, 2012.

Eva Halásová \& Daniela Reháková, Comenius University, Faculty of Natural Sciences, Department of Geology and Palaeontology, Mlynská dolina G, 84215 Bratislava, Slovak Republic; halasova@fns.uniba.sk •Zdeněk Vašičck, Institute of Geonics AVCR, Studentská 1768, 70800 Ostrava-Poruba, Czech Republic • Lubomír Jansa, Geological Survey of Canada-Atlantic, B2Y 4A2 Dartmouth, N.S. Canada $\bullet$ Petr Skupien (corresponding author), Institute of Geological Engineering, VŠB - Technical University Ostrava, 17. listopadu 15, CZ-70833 Ostrava-Poruba, Czech Republic; petr.skupien@vsb.cz.

The Czech national natural monument "Ostravice River Channel" located near to the Ostravice municipality by Frýdlant nad Ostravicí has been of an interest to the geological community and naturalists for a long time, since it clearly demonstrate the overthrust tectonics.

During repeated floods in the Ostrava region (and the Moravskoslezské Beskydy Mountains) in July 1997, August 2002 and again in May and June 2010, the bottom and the banks of Ostravice River were eroded and the exposure of strata several times rejuvenated. During the floods in the year 1997, a single river stream with the only rapids on the river was separated into two river arms by the development of additional, smaller rapids, as can be presently seen. The favourable exposure of sedimentary rocks enable to one of the authors to photographically document the locality during 1997 and together with M. Vašíčková carry out later a detailed geological documentation of the Ostravice River Channel natural monument. It included a geological structure study, specifically from a rock step with river rapids through the continuation of the bedrock outcrops up the river. The outcropping rocks belong to the Lower Cretaceous Silesian Nappe of the Outer Western Carpathians.

In the course of detailed geological study of the Ostravice River Channel natural monument section, samples were taken for thin sections and later another collection of samples focused on sampling limestone layers during a joint visit with the Bratislava colleagues to the locality in 2004 was made. The purpose of the latter sampling was to 


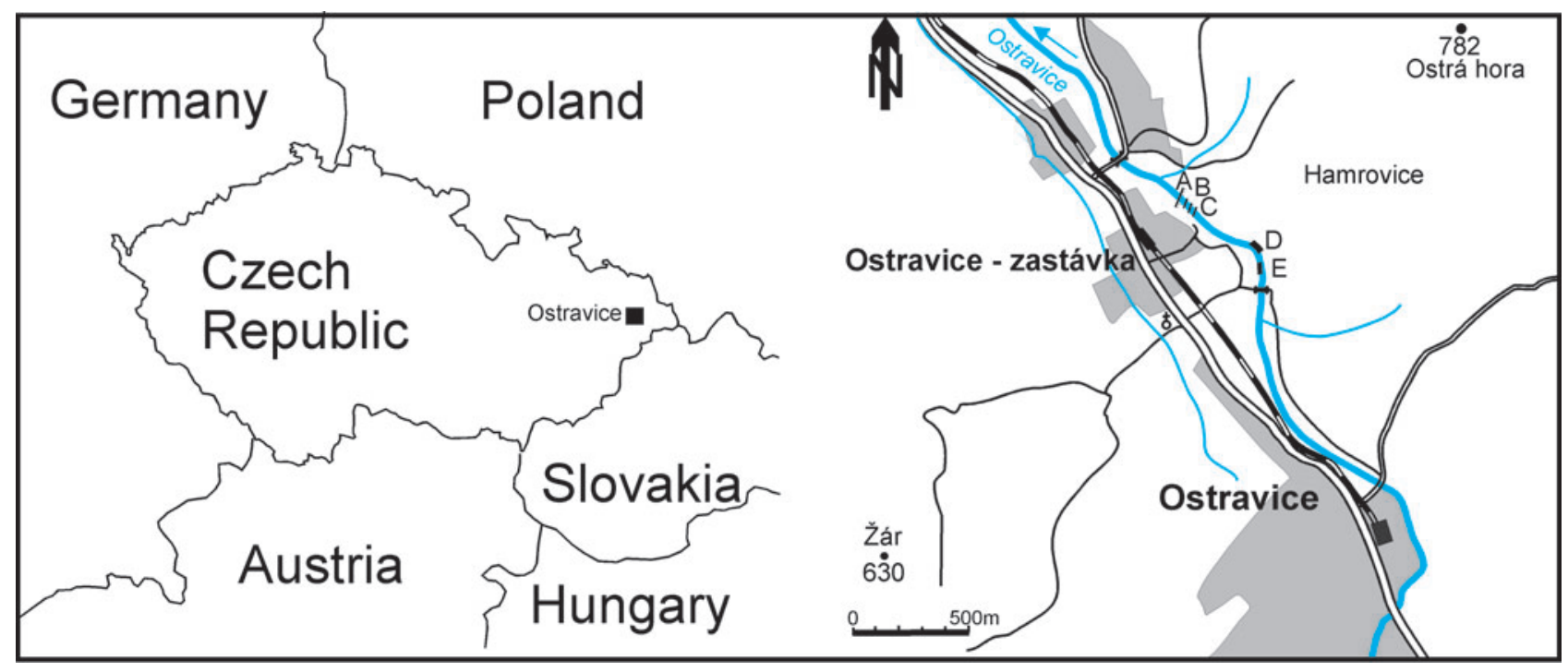

Figure 1. Topographic situation of national monument "Ostravice River Channel” with localities under study.

establish the age of the sedimentary strata using microfossils. In 2008 samples for thin sections were taken from outcrops on the left bank of river at the front of the rapids to the contact between the Silesian Nappe and the Subsilesian Nappe. At the end of the year 2010 and at the beginning of 2011 the new photographic documentation of the section was made. During early studies prior to 1997 and in several visits afterwards, no macrofossils were found in the section. During Ph.D. thesis preparation, P. Skupien attempted to extract non-calcareous dinoflagellates from samples of dark grey pelites, but also without success.

Due to complex geological structure of the locality and its ambiguous stratigraphic position, a team of specialists revised the section in the frame of their participation in the IGCP 463 Project Cretaceous Oceanic Red Beds. It included staff members of the Institute of Geological Engineering of VŠB - Technical University of Ostrava, supported by a grant GAČR No. 205/05/0985 (Cretaceous Oceanic Red Beds in the Czech Outer Carpathians). L. Jansa interpreted sedimentological data from thin sections and rock samples taken at the locality; E. Halásová and D. Reháková processed and evaluated the samples for the presence of calcareous nannofossils and calcareous dinoflagellates and P. Skupien processed the samples for non-calcareous dinoflagellates. The project was guided by Z. Vašíček, who provided regional geological setting and also coordinated international cooperation.

\section{Overview of previous investigations}

The Ostravice River Channel was officialy declared as a natural monument in 1966. It is better known in the geological community as rapids on the Ostravice River. It starts at about $300 \mathrm{~m}$ ENE of Ostravice's railway station - Zastávka, and about $350 \mathrm{~m}$ SE upstream from a road bridge across the Ostravice River, in the northern part of the Ostravice municipality area (see Fig. 1). The Ostravice rapids have been famous for a long time as a geological locality as they show the exposure of a thrust plane of the Silesian Nappe overlying the Subsilesian Nappe. For this uniqueness, many field trips were conducted to this area during geological congresses, conferences and meetings.

The most extensive guidebook to the Ostravice River Channel was written by Roth (1967) in the course of preparation for the $23^{\text {rd }}$ International Geological Congress in Prague in 1968. In addition to the overall description of the locality, Z. Roth constructed a geological section from strata exposed at that time by the river right bank; the section graphically illustrates geological structure in detail on a scale of $1: 182$. Furthermore, the section included a sketch on a scale of 1:278, showing the geology of both river banks, including outcrops of the Subsilesian Nappe, exposed contact between the Silesian and the Subsilesian Nappe and a part of the Hradiště Formation (with reference to the field documentation by Roth \& Hejcman 1965). Picture documentation concerns a stretch of about $30 \mathrm{~m}$ of the river right bank in the northernmost part of the locality (i.e. the geological situation downstream of the river rapids). The Lower Cretaceous deposits of the Silesian Nappe, at that time named the Těšín-Hradiště Formation, were regarded by Z. Roth as being of Hauterivian age. However, the age was not supported by any fossils.

Another field trip to the area led by E. Menčík in 1968 included a visit to the nappe contact in the Ostravice River. The description of the locality is similar to that in the guidebook by Roth (1967), but without any illustrations. 
In the lithological and sedimentological description development of the Těšín-Hradiště Formation in the Silesian Unit, Eliáš (1970) described in detail a small segment of the sequence exposed by the Ostravice River rocky tube, which consist of sandy flysch. This segment is a little more than $2.6 \mathrm{~m}$ thick and is illustrated as Fig. 3B. The exact position of the illustrated strata exposed by the river was not given.

For a field trip organised at the occasion of $10^{\text {th }}$ Congress of Carpathian Balkan Geological Association (CBGA), held in Bratislava in 1973, the locality was described again by Eliáš (1973), with reference to Roth (1967), and in a guidebook to a similar field trip led by Menčík (1973).

A brief description of the Ostravice locality is also provided in a guide for a field trip organised at the $60^{\text {th }}$ anniversary of the foundation for the Central Geological Institute in Prague by Eliáš et al. (1979). The age of the Těšín-Hradiště Formation was estimated as Hauterivian to Early Aptian. For the field trip, held in a connection with the IGCP project No. 362 in Smolenice in the year 1994, the locality was described by Vašíček in the field trip guide by Michalík \& Reháková (1994), which was devoted to the geology of Outer Western Carpathians. For the $17^{\text {th }}$ CBGA Congress, held in Bratislava in 2002, the locality was redescribed by Krejčí et al. in Vozár et al. (2002). Moreover, some data were presented in a field trip guide to Czech geological localities by Gába et al. (2002).

Results of the study of the uppermost exposed part of the Hradiště Formation, namely the continuation of the section upstream from the rapids, together with the overlying Verrovice Formation, studied for the organic carbon content in dark grey pelites, were published by Kratochvílová et al. (2003). Some preliminary results of a micropaleontological study of the Hradiště Formation concerning the rapids area were presented by Halásová et al. (2009) at the ESSE WECA Conference in 2008.

\section{Geological setting, outcrops descriptions and sampling}

The sedimentary strata exposed at the Ostravice Channel locality are part of the Cretaceous sequence of the Outer (Flysch) Western Carpathians. The exposure is located at the southern rim of the Frýdlant tectonic window. The locality is remarkable for the continuous exposure of the strata in the channel and on both banks of the Ostravice River, exposing a thrust surface of the Silesian Nappe, which overlies the Subsilesian Nappe. Associated tectonic melange within the overthrust can be observed directly at the surface. Sedimentary rocks of the lower, i.e. Subsilesian Nappe in the thrust zone belong to the Upper Cretaceous Frýdek Formation. According to Roth (1967), planktonic foraminifers present in marly deposits of this formation indicate Late Cretaceous (Maastrichtian) age.

The deposits of the Silesian Nappe from the overthrust zone up the river belong to the former Těšín-Hradiště Formation, redescribed as Hradiště Formation by Eliáš et al. (2003). The strata outcropping downstream and upstream from the rapids are supposedly of Early Cretaceous (Hauterivian - Aptian) age but without any biostratigraphical supporting data.

Sediments of the Silesian Nappe from the thrust plane with the underlying Subsilesian Nappe are described here from the bottom up, i.e. up the river. They were studied in 5 sectors designated A to E (see Figs 1 and 2). The Sectors A (with GPS coordinates at the beginning of the Sector, i.e. at its lower end N49 33.088 E18 22.978) and B (GPS N49 33.072 E18 22.988) are part of the natural monument; the Sectors C (GPS at the beginning of the Sector N49 33.061 E18 22.977), D (GPS - N49 33.003 E18 23.094) and E (GPS - N49 32.935 E18 23.250) are located farther upstream, outside of the monument area.

The outcrops of the Hradiště Formation in the area of the natural monument as already said above were subdivided into two parts: Sector A and Sector B. The lower outcropping part of the formation, which can be observed downstream from the rapids (Sector A, Fig. 2), represents a stretch of strata exposed on both the left and the right bank of the river. The outcrop of the strata on the left river bank begins with the exposed contact of the nappes and continues up the river as far as the rock step, which forms the base of the river rapids. On the left bank of the river outcrop is represented at first by the $43 \mathrm{~m}$ long continuous exposure of strata, and then by other $12 \mathrm{~m}$ of poorer exposed section at the shoreline zone of a river pool, downstream from the rapids. On the right bank, the exposure of rocks is more continuous but harder accessible. With regard to the different position of the thrust plane of the Silesian Nappe at the left and the right bank, the equivalent stretch of the Lower Cretaceous deposits in the section on the right river bank is longer by about $5 \mathrm{~m}$ than on the left bank. Thus, the total length of the exposure is about $60 \mathrm{~m}$.

The arrangement of strata of the Sector A is more complex as they are affected by the close proximity to the thrust plane of the Silesian Nappe. The thrust zone itself is about $1 \mathrm{~m}$ thick and consists of dark grey mylonitic clay, into which in the uppermost part (Fig. 3A) are wedged lightcoloured fragments of younger rocks of the Subsilesian Nappe. The Hradiště Formation outcropped above the thrust plane of the Silesian Nappe is of flyschoid character. The psammitic component (subgreywacke) is approximately in equilibrium with grey to dark grey siltstones and calcareous claystones. A single, different, non-repeating component in the first part of the section is a $30 \mathrm{~cm}$ thick layer of conglomerate. The section on the left bank is tectonically folded, complicated by strata dislocations. The 


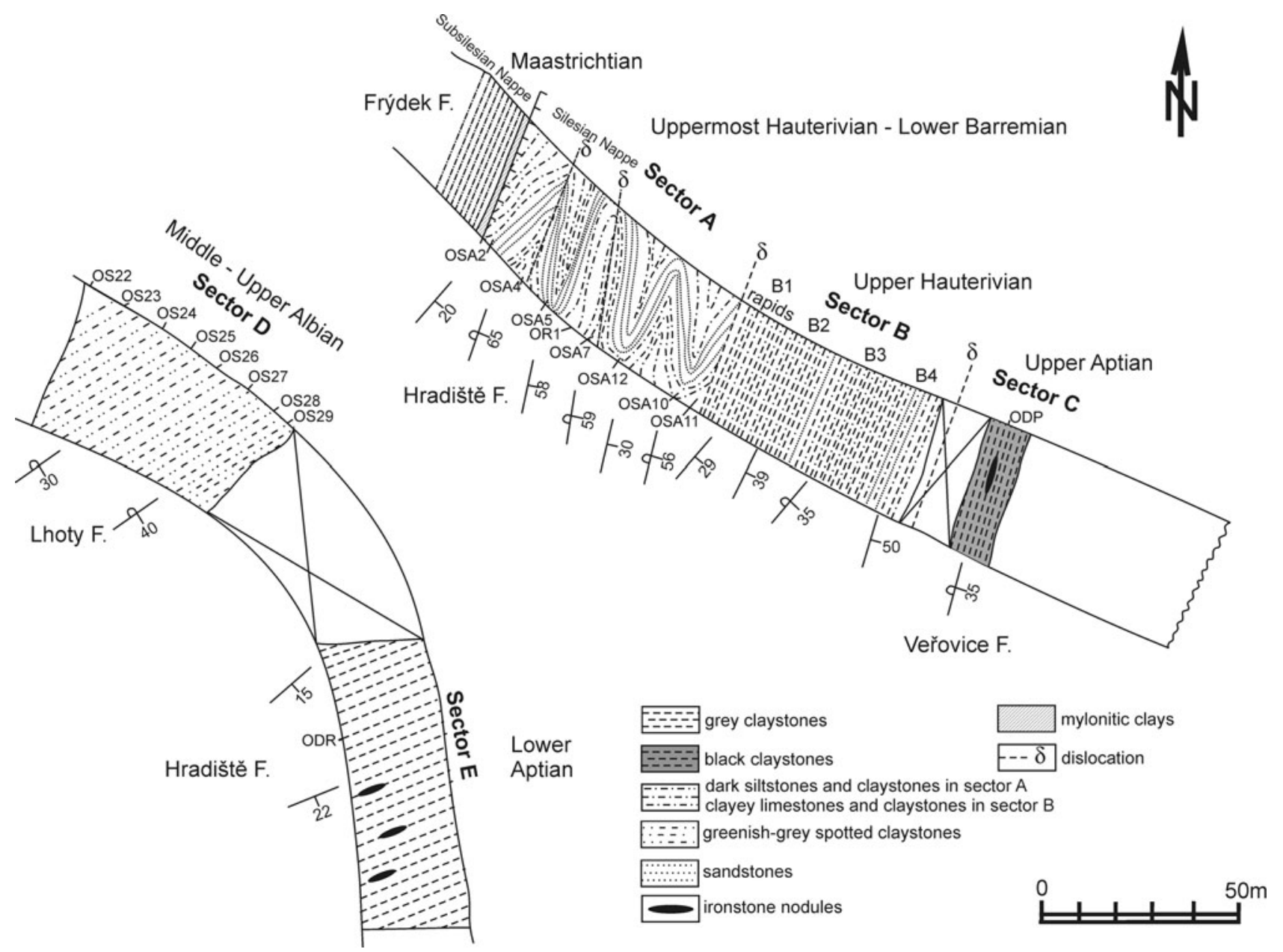

Figure 2. Schematic geology and lithostratigraphic classification of sequences studied, divided into Sectors A-E. Sector B is devided to B1-B4 segments (see text).

presence of tight folds is documented by several alternations of normal and overturned strata. Without presence of distinct lithological marker beds, it is not possible to conclude which of the changes are the results of tectonics and which are of sedimentological/paleoenvironmental nature (Fig. 3B).

The beginning of the sampling line $(0 \mathrm{~m})$ of samples for micropalaeontology and thin sections in the Sector A (Fig. 2) corresponds to the first, relatively strong, psammitic bed at the close proximity to the plane of the thrust of the Silesian Nappe. Samples OSA 2 to OSA 12 were taken for micropaleontology from clayey layers. A detailed lithological description of all 11 samples collected is given in an Appendix. The first sample (OSA 2 - dip direction of beds in normal position of strata is 187/20) was taken from the claystone $3 \mathrm{~m}$ above the lowermost flat-lying sandstone bed (level $0 \mathrm{~m}$ ). Another sample (OSA 3) was taken from claystones at $10 \mathrm{~m}$ (160/24 - strata in normal position). A subsequent sample (OSA 4) was taken at $18 \mathrm{~m}$ (180/55 in overturned strata). These two sequences are perhaps sep- arated from each other by a fault. At $21.3 \mathrm{~m}$ (144/58 - normal position of strata), sample OSA 5 was collected. At $24 \mathrm{~m}$, after the stretch of strata in normal position, a zone of coarse flysch within the overturned sequence of strata is present. At $25 \mathrm{~m}$ there is a $30 \mathrm{~cm}$ thick layer of "tilloid" conglomerate, enclosing a grey matrix of poorly reworked pebbles and fragments of pelitic rocks and lighter grey limestone. They are $1-3 \mathrm{~cm}$ in size. In the matrix was found a single, incomplete and indeterminable remnant of a belemnite guard. From the lower part of the conglomerates, sample OR 1 was taken for thin section study. Within overturned strata (146/53), another sample was collected from a claystone layer - sample OSA 6, taken at $25.8 \mathrm{~m}$. At $34.8 \mathrm{~m}$ in a tectonically disturbed and complicated zone (152/59 - overturned strata), sample OSA 7 was taken from claystones close above the sandy sample OSA 8 at $35.2 \mathrm{~m}$. Below the spring outflow by stairs at $38 \mathrm{~m}$, an additional sample OSA 12 (140/44 - normal position of strata) was taken from the claystones (i.e. this sample out of turn). 

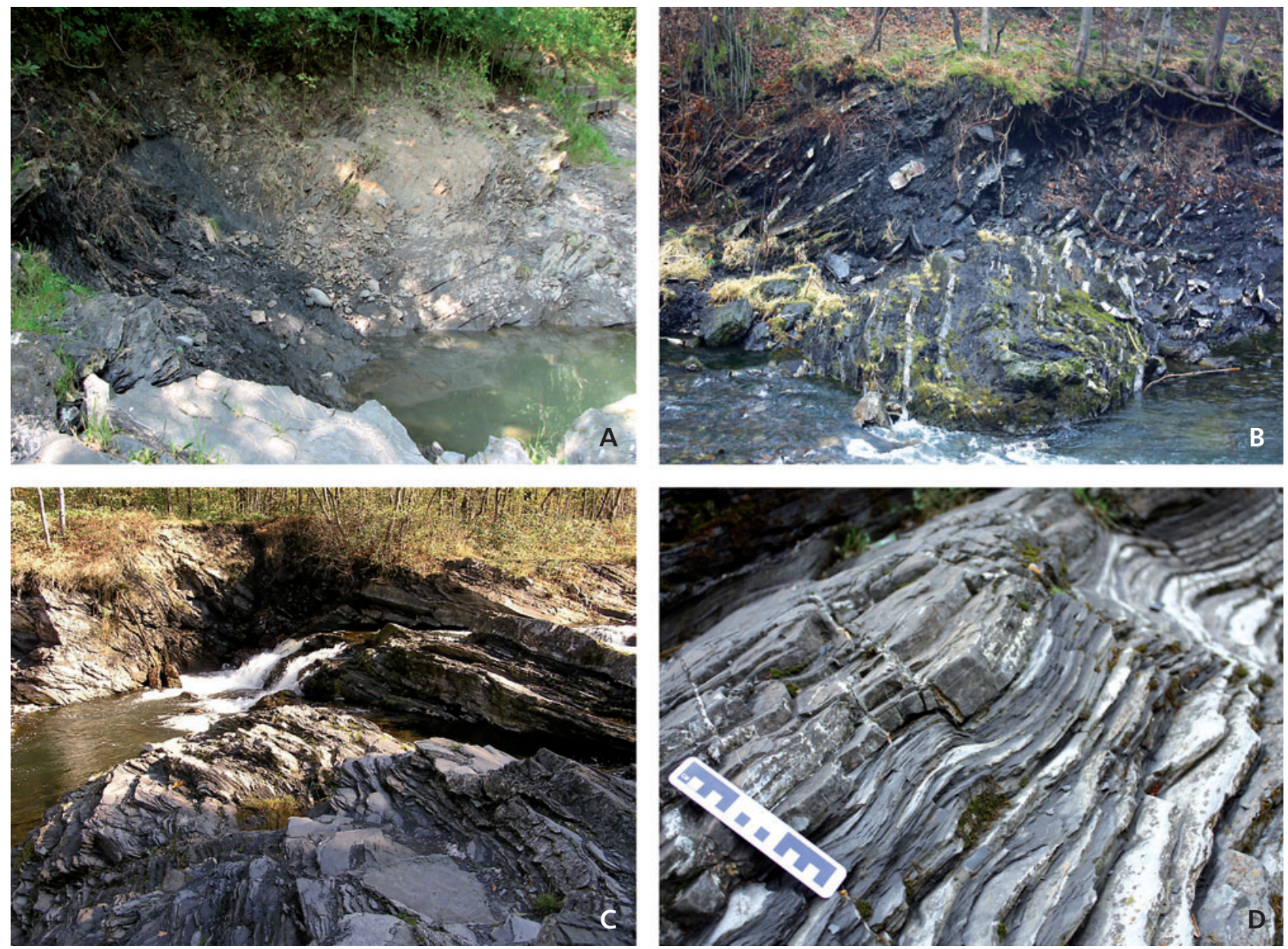

Figure 3. A - contact zone between the Silesian Nappe (left side) and the underlying Subsilesian Nappe (right side) on the left river bank (photo: $\mathrm{Z}$. Vašíček, 2010). • B - folded and tectonically disturbed deposits of Hradiště Formation (Sector A) exposed on the left bank (photo: O. Malek, spring 2011). C C - front view of river rapids showing Segment 1 (left side) and the beginning of Segment 2 (right side) of Sector B with three layers of amalgamated sandstones (photo: P. Skupien, 2010). D - detail of rhythms with limestone in Segment 1 of Sector B at the edge of rapids (photo: P. Skupien, 2011).

From the spring level towards the rapids, the strata are less perfectly exposed and were overlain by detritus at the end of the year 2010. In this mostly covered sequence, calcareous pelites predominate; each layer of the pelites is about $1 \mathrm{~m}$ thick. These pelite layers are intercalated with sandstone beds. The thickness of each of the sandstone beds is ranging from 10 to $30 \mathrm{~cm}$. In the given stretch of exposure at $46.3 \mathrm{~m}$ (147/72 - overturned position), a sample of claystones OSA 9 was taken; at $47 \mathrm{~m}$ (strata dip is about 90 degrees), sample OSA 10 and at $48.5 \mathrm{~m}$ (crushed zone of overturned strata), sample OSA11 were taken. At the end of the Sector A, directly below the rapids, the dip direction of the strata in an overturned position is 151/56.

The Sector A is separated from the overlaying strata of Sector B (Fig. 2) by a fault.

The outcrops of Sector B was documented in detail (Fig. 5A, B). Section begin with the lowermost member of the strata building the rock threshold of the rapids. At the left bank of this strata segment, a striking sandstone layer of variable thickness of up to $30 \mathrm{~cm}$ thick outcrops at the base of the Sector B. This layer continues farther to the right bank across the river. In the central part of the river bed (towards the right bank) the continuity of the basal part of the latter zone is interrupted by an oblique fault with a dip direction of 110/44 deg.

The sequence of strata within the Sector B continues along the left bank for about $46-48 \mathrm{~m}$. The composition of this section is monotonous, with the strata comprised by pelagic limestones, claystones with intercalations of sandstones. Bedding is monoclinal. According to the lithological composition and position of the strata, four lithostratigraphical segments can be delineated.

Fifteen samples in the Sector B were obtained for micropaleontological analyses from outcrops of micritic limestones and calcareous claystones in the Sector B. The position of the samples is depicted in Fig. 5A, B by capital letters: ODA - ODO. A detailed description of all micropaleontological samples is given in the Appendix. 
The samples for the thin section analyses, mainly from the part where limestones are present and continued farther up, where limestones become rare and gradually disappear. From the representative rocks, 10 thin sections from limestones, 4 from sandstones and 1 from the sandstone containing limestone intraclasts were prepared. The position of the samples is illustrated in Fig. 5A, B. A detailed description of all thin sections is given in the Appendix.

The first segment includes the rock step that forms the river rapids (Fig. 3C). The beds are in the normal position. On the left bank, this segment is $7.4 \mathrm{~m}$ thick (see Fig. 5A, segment 1). The strata are formed by the alternation of several centimetres thick rhythms (most frequently $4-8 \mathrm{~cm}$, sporadically up to $30 \mathrm{~cm}$ thick) composed of alternating light grey clayey limestones and grey calcareous claystones. Some of the $1-10 \mathrm{~cm}$ thick rhythms have several millimetres to centimetre thick beds of sandstone at the base, which grade stratigraphically upwards into limestone and claystone (Fig. 3D). In the thicker rhythms, the thickness of the sandstone is about $10 \mathrm{~cm}$ with the thickest bed being about $20 \mathrm{~cm}$ thick.

In the first segment of strata the beds are in normal positions (the dip direction is 132/29). From here the samples of limestones OV 1-3, OV 6, OV 8 (see Fig. 5A) were taken.

The fault along the strike at the left bank up the river is followed by the second segment of the studied section (Fig. 5A, segment 2). It is $6.1 \mathrm{~m}$ thick, with beds in normal position (dip direction 116/39). In the lower part of this second segment, three thin to medium thick sheet-like sandstone beds of variable thickness are present. The thickness of the lowermost bed, which is exposed on the left bank, increases over a short distance from $30 \mathrm{~cm}$ to $75 \mathrm{~cm}$. Foldyna (1964) interpreted the variable thickness of sandstones as boudinage. The thickest, graded-bedded sandstones are usually medium-grained at the base. In the uppermost part of the second segment, the sandstone flysch is replaced by a fine-rhythmic flysch, lacking sandstone and limestone intercalations. At the end of the second segment, at the base of the outcrop zone on the left bank pelitic sediments in an eroded trough occur.

In the beds of the second segment no samples for thin sections were taken.

Continuing up the river, the third segment crops out (Fig. 5A, segment 3). It is $3.25 \mathrm{~m}$ thick and the strata are overturned (116/35). It is comprised of finely rhytmic flysch. Clayey limestones and grey pelites predominate, similarly to the first segment of the section. Only two sandstone beds, $10-15 \mathrm{~cm}$ thick are intercalated here. On the lower bedding planes of thicker limestone layers about $15 \mathrm{~mm}$ wide trails of invertebrates (Fig. 4A) and narrow wiggle-shape trace fossils are present. The sequence of strata of the third part ends with a fault.
The sample OTV3 was taken in the third segment (Fig. 5A).

Upstream from the above-mentioned fault, at the left bank the fourth, uppermost segment of the section is exposed (Fig. 5A, segment 4). The strata are in normal position (dip direction 124/34), with this segment being about $10 \mathrm{~m}$ thick. In its uppermost part, the outcrop is still continuous, however further upstream it gradually disappears. At the beginning of the section, limestone-claystone rhythms predominate. Further up, sandstone beds become more frequent and their thickness gradually increases. The uppermost conspicuous sandstone bed, composed of two, in places three amalgamated layers separated by bedding joints, has a variable thickness of 60-90 cm. The sandstone is overlain by a "tilloid" conglomerate bed of variable thickness, ranging from 24 to $42 \mathrm{~cm}$. The sandstone is separated from the conglomerate by a layer of grey pelite of variable thickness from several $\mathrm{cm}$ up to $20 \mathrm{~cm}$.

At the beginning of the fourth segment, samples OTV 1, OTV 2 (limestones) and OTV 4 (conglomeratic sandstone) were taken.

The sequence of strata above the described sandstone bed represents the end of the exposure of the Hradiště Formation on the left bank. The uppermost part of the Hradiště Formation at this place can be connected with the section outcropping on the right bank of the river (Fig. 5B, segment 4), where it is $16 \mathrm{~m}$ thick. The stratigraphically youngest part of the exposed Hradiště Formation in this location, $9 \mathrm{~m}$ in thickness, was described in detail by Kratochvílová et al. (2003, Fig. 1).

In this part of the Hradiště Formation, which is exposed on the right bank, the clayey limestones appear for the last time (Fig. 4B). After a short interruption in the exposure near the end part of the sequence at the right bank, limestone layers disappear. The interruption in the section is probably connected with an overthrust fault, as the dip direction of strata in the foot wall of the fault is $105 / 41 \mathrm{deg}$. In the hanging wall, the dip direction of strata is variable. The strata are folded and dip direction oscillate between 110/62 and $128 / 70 \mathrm{deg}$.

In the uppermost part of the outcroped Hradiště Formation there the pelitic component continues to predominate. It is comprised of grey to dark grey calcareous claystones. In the final nine metres, two sandstone beds of variable thickness are embedded. The thickness of the lower sandstone stained by iron oxides varies from 20 to $30 \mathrm{~cm}$. The overlying sandstone is 18 to $26 \mathrm{~cm}$ thick. Distinct layers of sandstones in the uppermost part of the sequence are usually about $10 \mathrm{~cm}$ thick.

The samples OSV 1, OSV 2 (the last limestones), OSV 7 (sandstone) and OSV 8-10 were taken. The sample OSV 8 was taken from sandstone about $20 \mathrm{~cm}$ thick near the short interruption in the strata exposure. The sample OSV 9 is from a $5 \mathrm{~cm}$ thick sandstone layer higher in the strata. From the uppermost slab-like sandstone layer of 

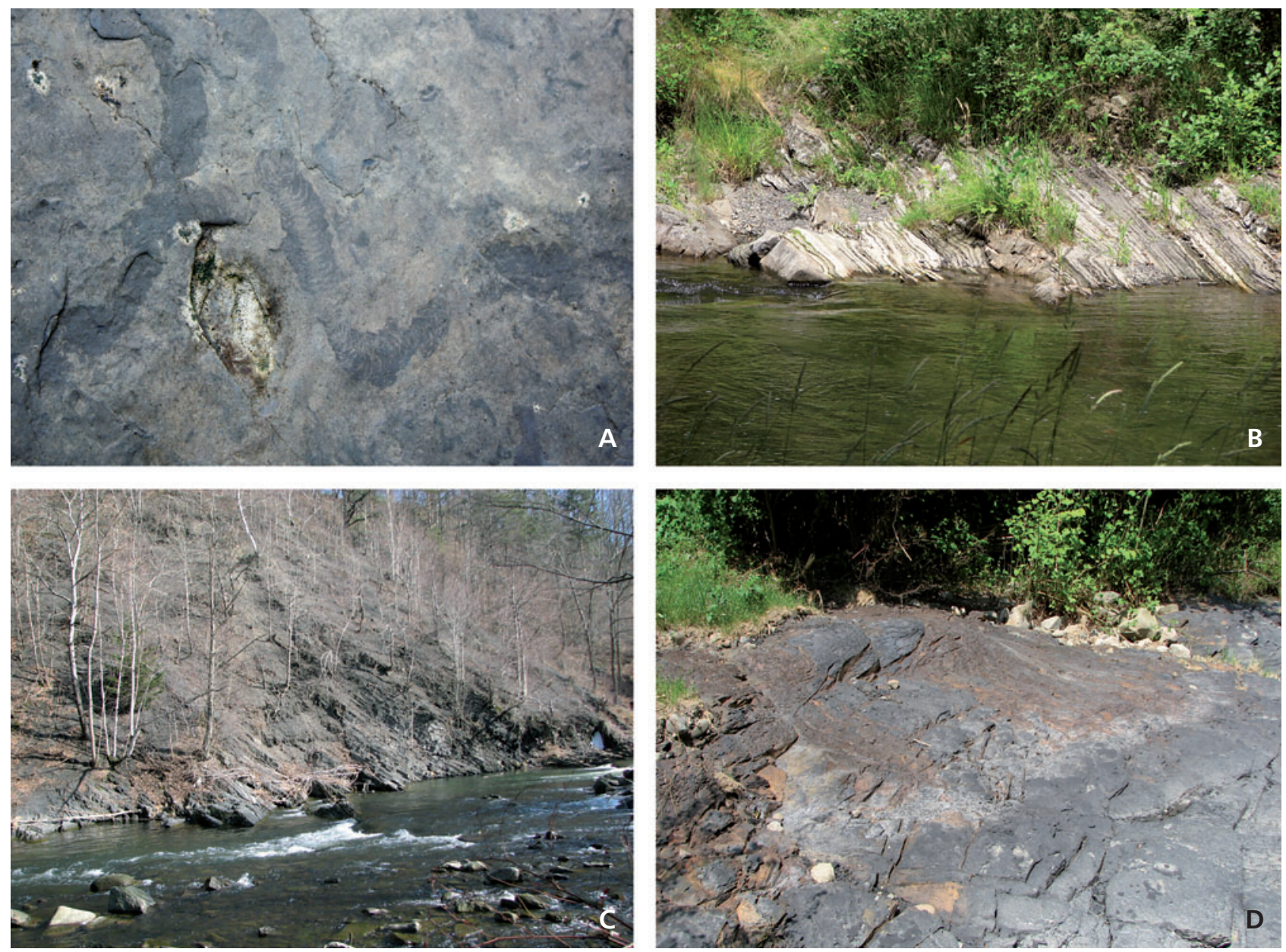

Figure 4. A - ichnofossil of Taenidium planicostatum Uchman, 2007 on a lower bedding of limestone layer of Segment 3 (Sector B), marked with checkered line in Fig. 5A (photo: O. Malek, spring 2011). B - gradual disappearance of limestone layers (to the right) in the Hradiště Formation on the right river bank (photo: Z. Vašíček, summer 2009). • C - outcrop of the Lhoty Formation (Sector D) on the right river bank (photo: Z. Vašíček, spring 2011). D - Lower Aptian flat-lying pelites of the Hradiště Formation of Sector E (photo: Z. Vašíčck, spring 2011).

Sector B, which is a weathered in a rusty colour, a sample was collected for thin section OSV 10 . The sample was positioned $55 \mathrm{~cm}$ above the sample ODO.

The length of the sector B on the right bank (Fig. 2) is about $44 \mathrm{~m}$. After interruption of the section for about $13 \mathrm{~m}$ the outcrops discontinuously continue for additional $300 \mathrm{~m}$. In its lowermost part (Fig. 2, Sector C) on the right bank of the river, a $5.5 \mathrm{~m}$ thick zone of black-grey, strongly tectonically deformed non-calcareous claystones enclosing a layer of lenticular clayey ironstones (up to $30 \mathrm{~cm}$ thick) belong to the Veřovice Formation. Sole marks on the top of one of the bedding planes of fine-grained sandstone indicate overturned position (dip direction 108/40).

From the claystone of the Veřovice Formation sample ODP was taken.

Next large exposure (overlying the right bank after an interruption) in the outcrop at a river turn represents the Lhoty Formation (Fig. 2, Sector D, Fig. 4C). The strata are comprised of grey to greenish-grey predominantly pelitic deposits, frequently spotted with chondrites. These shales resemble the typical Tethyan lithofacies known as Scisti di Fucoidi, which can also be seen at the Bystrá locality in another section of the Silesian Unit (see Boorová et al. 2008). The Lhoty Formation strata are overturned (dip direction of strata is $156 / 30$ at the beginning of the outcrop and at the end of the outcrop 158/40).

From the pelitic rocks of the Lhoty Formation, eigth samples (Os22-29) for the non-calcareous dinoflagellates were taken.

After another interruption in the strata exposure, the outcrop continues with the next part of the section (Fig. 2, Sector E). It is situated at the boundary of the southern end of the football field in the municipality of Ostravice. The outcropping strata on the left bank of the Ostravice River terminate near the foot bridge. Flat-lying pelitic rocks outcropping here (dip direction 136/15 to 152/22) represent the upper part of the Hradiště Formation (Fig. 4D). The claystones are grey to dark grey and usually crumble. On 
Bulletin of Geosciences • Vol. 87, 2, 2012

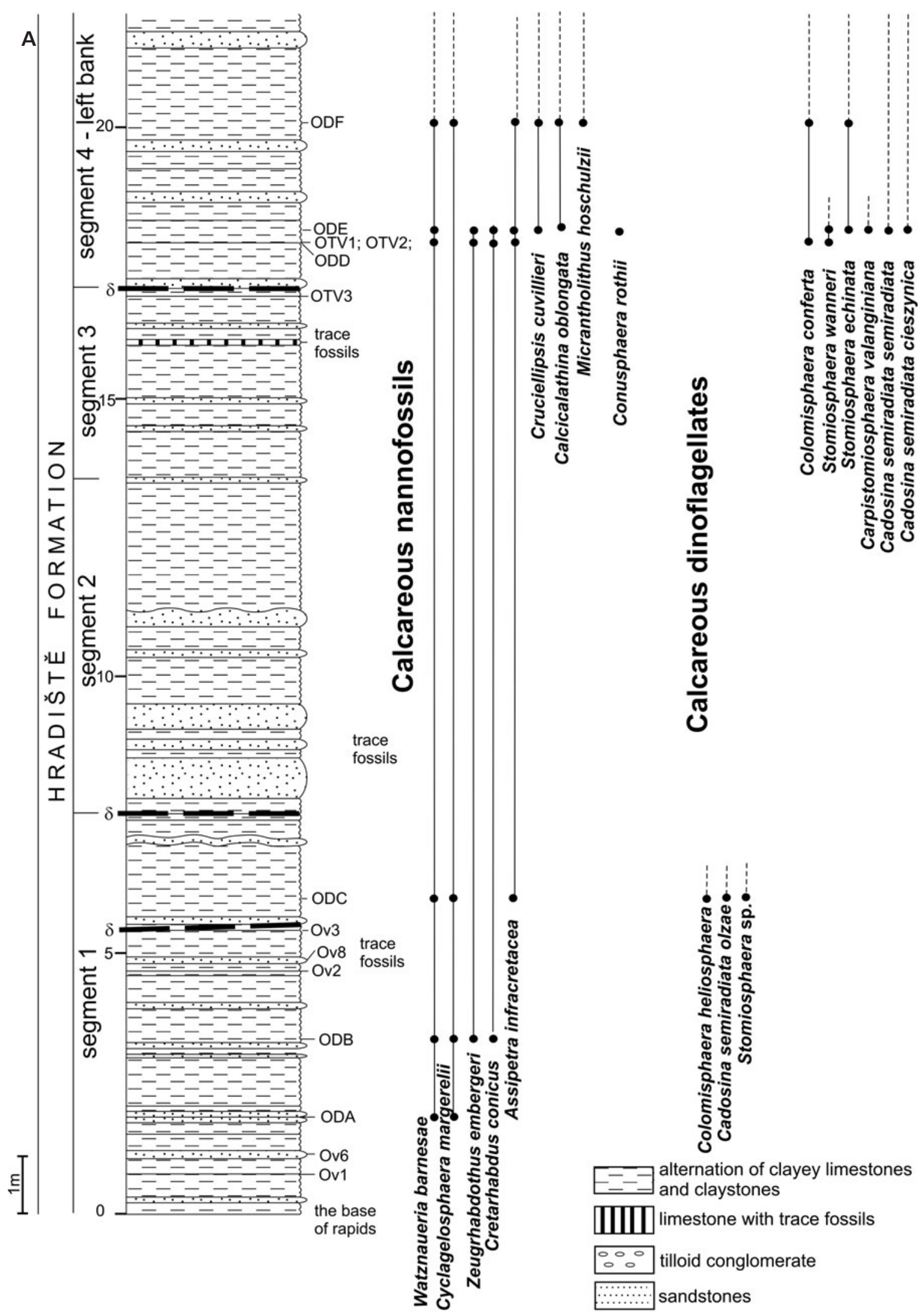

Figure 5. Detail cross-section through deposits of the Hradiště Formation of Sector B, divided into partial Segments 1 to 4 with locations of micropaleontological samples and samples for thin sections; A - lower part of the section, B - upper part. 
Eva Halásová et al. • Lower Cretaceous succession and biostratigraphy near overthrust plane of Silesian Nappe

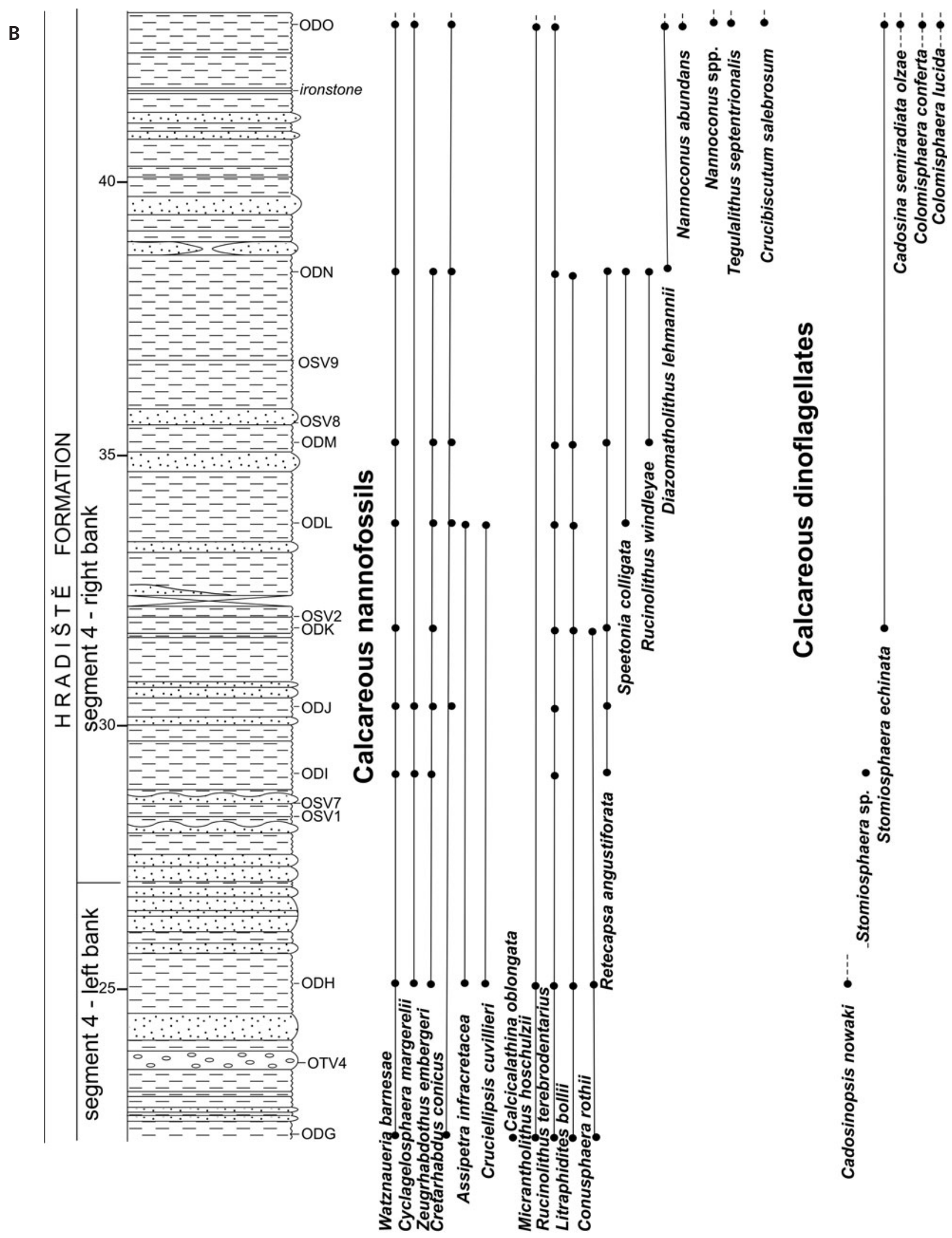


bedding planes and fissures a rusty limonitic coating is common. At two places the claystones slightly fizz when tested with the $\mathrm{HCl}$ acid, indicating that some are slightly calcareous, but otherwise all exposed claystones are non-calcareous. The strata enclose layers of lenticular to loaf-like, heavily fissured clayey ironstone concretions, up to $40 \mathrm{~cm}$ in diameter. The thickness of the exposed strata is about $25 \mathrm{~m}$. Sample ODR was taken here.

In the whole Ostravice River Channel outcrop, only five shells of ammonites have been found during past 16 years, namely in the Hradiště Formation in the Sector E. One of the ammonites belongs to the index species Paradeshayesites weissiformis (Bogdanova), which documents the Early Aptian age of the deposits (Vašíček et al. 2004). Another species-determinable ammonite found in 2005 is P. semenovi (Bogdanova) - see Vašíček (2008), indicating similar age. Also the other shells found are merely fragments belonging to deshayesitid ammonites.

\section{Methods}

Calcareous nannofossils found in claystones and micritic limestones were studied. Smear slides were prepared from sampled sediments using the standard technique (Bown \& Young 1998) and studied under an OLYMPUS BX 50 light microscope at a magnification of $\times 1250$. Photodocumentation of nannofossils was performed by CAMEDIA digital camera C-4000 Zoom.

Sample material, slides and light microscope images are housed at the Department of Geology and Palaeontology, faculty of Natural Science at the Comenius University of Bratislava.

Microfacies analyses focused on microfossil distribution (in this case mainly on calcareous dinoflagellates) were studied under the light microscope LEICA DM 2500-P in 30 thin sections. Cysts were documented by a LEICA DFC 290 HD camera. Thin sections are deposited in the Department of Geology and Palaeontology, Faculty of Natural Sciences in Bratislava.

A total of 49 rock samples (15 from Sector A, 15 from Sector B, 8 from Sector C, 6 from Sector D, and 5 from Sector E), mostly recovered from the dark claystone beds, were taken for non-calcareous dinoflagellate study. Only samples from Sector D provided dinoflagellate cysts. Samples were processed by a standard palynological technique, that is, by dissolution in $\mathrm{HCl}$ and $\mathrm{HF}$ with subsequent sieving on polyethylene sieves with a mesh size of $15 \mu \mathrm{m}$. The palynological permanent mounts are stored at the Institute of Geological Engineering at the VŠB - Technical University of Ostrava, Czech Republic.

\section{Thin section analyses}

Rock composition in the studied Ostravice Section is relatively monotonous; the rocks are mostly pelitic. Therefore, thin section analysis of sandstones was used to provide some information about depositional conditions of exposed sedimentary rocks. In the lowermost part of the section in the Hradiště Formation exposed in the natural monument (Sector A), sandstones and grey calcareous claystones rhythmically alternate. In the next part of this Formation near the "rapids" (Sector B) and higher up the river, there is a multiple repetition of pale grey pelagic limestones intercalated with grey calcareous claystones and rare sandstone beds. The sandstones in the beds are of variable grain size. The overlying Veřovice Formation is predominantly comprised of dark grey, non-calcareous claystones. The stratigraphically highest Lhoty Formation is again pelitic in composition. It consists of grey and greenish-grey claystones commonly containing trace fossils of chondritic type, which are visible on bedding planes. These spotty claystones are non-calcareous, or only slightly calcareous.

The limestones of the Hradiště Formation in the area of rapids are micritic. They can be classified as nannomicrites, or biomicrites, as some calcareous nannofossils are partly preserved in the limestone matrix. Exceptionally, very poorly preserved pelagic foraminifers also occur. Radiolarians replaced by calcite are quite common (1-5\%). Trace amounts of ostracod shells, sponge spicules, and some indeterminable, very fine skeletal detritus were found (7-10\%). The swirl-like arrangement of fossils resembles burrowing activity, and reworking of the material. The limestones contain a subordinate amount of silt-sized quartz. The rocks can be classified as pelagic carbonates. The presence of the quartz silt indicates deposition at, or proximal to the continental margin.

Figure 6. Calcareous nannofossils. A - Watznaueria barnesae (Black) Perch-Nielsen; sample OSA 11.・B - Watznaueria manivitae Bukry; sample OSA 9. • C - Cyclagelosphaera margerelii Noël; sample ODO. $\bullet$ D - Eiffellithus windii Applegate \& Bergen; sample OSA 12. $\bullet$ E - Eiffellithus primus Applegate \& Bergen; sample OSA 12. • F - Eiffellithus striatus (Black, 1971) Applegate \& Bergen; sample OSA 12. • G - Rhagodiscus dekaenelii Bergen; sample OSA 11. • H - Diazomatolithus lehmanii Noël; sample OSA 10. • I - Helenea chiastia Worsley; sample OSA 12. • J - Retecapsa angustiforata Black; sample OSA 2. $\bullet \mathrm{K}-$ Cretarhabdus striatus (Stradner) Black; sample OSA $10 . \bullet$ L - Tubodiscus jurapelagicus (Worsley) Roth; sample ODL. • M - Tubodiscus verenae Thierstein, emend. Grün; sample OSA 12. • N - Discorhabdus ignotus (Gorka) Perch-Nielsen; sample ODH. - O - Calcicalathina oblongata (Worsley) Thierstein; sample OSA 12. • P - Calcicalathina oblongata (Worsley) Thierstein; sample ODF. $\cdot \mathrm{Q}$ - Cruciellipsis cuvillieri (Manivit) Thierstein; sample ODO. $\bullet$ R - Speetonia colligata Black; sample ODL. $\bullet$ S - Crucibiscutum salebrosum (Black) 

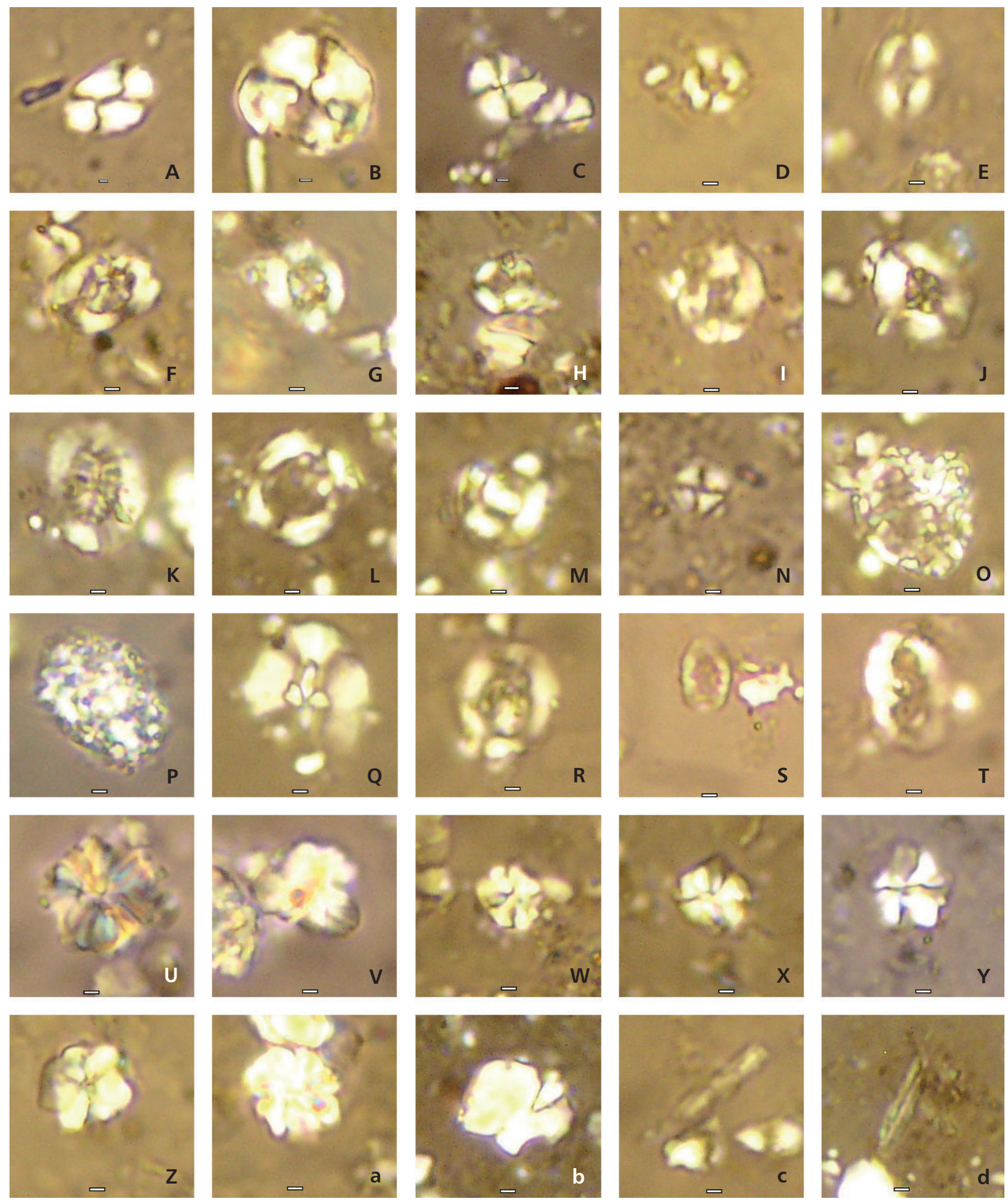

Jakubowski; sample ODO. • T - Zeugrhabdotus scutula (Bergen) Rutledge \& Bown; sample ODO. •U - Tegulalithus septentrionalis (Stradner) Crux; sample ODO. $\bullet \mathrm{V}$ - Nannoconus abundans Stradner \& Grün; sample ODO. $\bullet \mathrm{W}-$ Rucinolithus terebrodentarius Applegate, Bralower, Covington \& Wise in Covington \& Wise; sample ODJ. - X - Rucinolithus terebrodentarius; sample OSA 12. - Y - Rucinolithus terebrodentarius; sample OSA 2. $\cdot \mathrm{Z}-$ R. terebrodentarius; sample OSA 12. $\bullet \mathrm{a}-$ Rucinolithus windleyae Rutledge \& Bown; sample OSA $11 . \bullet \mathrm{b}-$ Assipetra infracretacea (Thierstein) Roth; sample OSA $10 . \bullet \mathrm{c}$ - Litraphidites bollii (Thierstein) Thierstein; sample ODL. $\bullet \mathrm{d}$-Lithraphidites carniolensis Deflandre, sample OSA 2. Micrographs taken by light Olympus BX 50 microscope, objective magnification 100×, CAMEDIA digital camera C-4000 Zoom. Scale bar $=1 \mu \mathrm{m}$. 
Sandstones from the lower part of the section are mostly fine-grained and cemented by calcite. They are usually medium-sorted, with subangular, sometimes angular grains. Plutonic quartz is dominant, with a subordinate amount of metamorphic quartz. K-feldspar (or perthitic feldspar) is present. The interparticle space is filled with sparry calcite cement. Small amounts of bioclasts are present, such as remnants of poorly preserved planktonic and benthic foraminifers, sponge spicules, detritus of thick-shelled mollusks, echinoid spines and calcareous algae.

In the uppermost part of the section, the sandstones are medium- to coarse-grained. The medium-grained ones are moderately sorted, with quartz grains being subangular in shape. In the coarse-grained sandstones, well-sorted and well-rounded grains dominate. Clusters of peculiar carbonate cement (pseudomorphs after aragonite or of bacterial origin?) and large fragments of algae (Dasycladaceae?) are present. The algal fragments are associated with detritus of thick-shelled molluscs, echinoids and fish bones.

The sandstones are of turbiditic origin (Ta) with bioclastic debris sourced from the shelf. The sandstones with algal detritus indicate a shelf, photic-zone depositional environment for the bioclasts.

Thin sections from a deposis macroscopically resembling a medium-grained "tilloid" conglomerate, embedded in the lower part of the Hradiště Formation, are gravelly to fine-grained gravel sandstones with intraclasts of limestones and rip-up clasts of marlstones. The clasts are dispersed in finer sand. The cement is carbonate. The quartz grains are up to $4 \mathrm{~mm}$ in size; they are very well rounded, but poorly sorted. The quartz is mostly of plutonic origin. The intraclasts are represented by small rounded pebbles of limestones and bioclastic limestones, up to $7 \mathrm{~mm}$ in size; some of them containing remnants of poorly preserved calpionellids. The presence of limestone intraclasts indicate erosion of an underlying carbonate platform comprised of Upper Jurassic to early Lower Cretaceous carbonates.

The description of thin sections of pelitic rocks sampled for the occurrence of calcareous dinoflagellates is included in the chapter on calcareous dinoflagellates.

\section{Calcareous nannofossils}

Calcareous nannofossils assemblages of the samples ODA to ODO and OSA 2 to OSA 12 sections are marked by poor preservation with an evidence of dissolution. Biostratigraphic analysis of these samples follows reference to the Lower Cretaceous zonation scheme after Bown et al. (1998), Channell et al. (1995), and includes zonation concept of Bralower (1987), who modified Roth's NC zones (1978, 1983).

\section{Samples ODA-ODP}

Low diversity nannofossil assemblages were observed in samples ODA-ODO (sample ODP from Veřovice Formation was barren in calcareous nannofossils). Undeterminable rests of heterococcoliths often occur. Typical in the assemblage is the dominance of Watznaueria barnesae and common is Cyclagelosphaera margerelii, in most of the samples. Rare nannoconids are present in the ODO sample (Nannoconus abundans?, Fig. 6V, Nannoconus spp.), which together with Crucibiscutum salebrosum (Fig. 6S), Tegulalithus septentrionalis (Fig. 6U) are typical for the boreal realm. From the biostratigraphical point of view the occurence of Calcicalathina oblongata (ODE, ODF, ODG), Fig. 6O, Cruciellipsis cuvillieri (samples ODE, ODF, ODH, ODL), Fig. 6Q, Speetonia colligata (samples ODI?, ODL, ODN), Fig. 6R, Litraphidites bollii (ODG, ODH, ODK, ODL, ODM, ODN), Fig. 6c, Rucinolithus terebrodentarius (ODG, ODH, ODI, ODJ, ODK, ODL, ODM, ODN, ODO), Fig. 6W, Rucinolithus windleyae (ODM, ODN) could indicate the age of deposits studied. The mentioned species determined in ODE to ODN samples indicate Late Hauterivian NC 5A, NC 5B Subzones (Bralower 1987, Bown et al. 1998, Channel et al. 1995). ODO sample has Late Hauterivian affinity, as well as it fits broadly to the assemblages of the BC 9 Zone (sensu Švábenická 2008).

\section{Samples OSA 2-OSA 12}

Calcareous nannofossils assemblages of the samples OSA 2 to OSA 12 are marked by low diversity with many undeterminable rests of nannofossils occurring. Abundance of Watznaueria barnesae and Cyclagelosphaera margerelii present in all samples; Assipetra infracretacea (OSA 7, OSA 10, OSA 11, OSA 12), Fig. 6b, Lithraphidites carniolensis (OSA 12), Fig. 6d, Zeugrhabdotus spp., Cretarhabdus spp. and absence of Litraphidites bollii and Nannoconus are typical features. The extremely rare badly

Figure 7. Calcareous dinoflagellates. • A - Colomispahera heliosphaera (Vogler); sample ODC1. • B - Cadosina semiradiata olzae (Nowak); sample ODC1. • C - Stomiosphaera sp.; sample ODC. • D, E - Cadosina semiradiata olzae (Nowak); sample ODC1. • F - Colomisphaera conferta Řehánek; sample ODD. • G, H - Stomiosphaera sp.; samples ODD, ODE. • I, J - Stomiosphaera echinata Nowak; sample ODE. • K - Cadosina semiradiata cieszynica (Nowak); sample ODE. $\bullet$ L - Cadosina semiradiata semiradiata Wanner; sample ODE. Scale bar $=100 \mu \mathrm{m}$. 

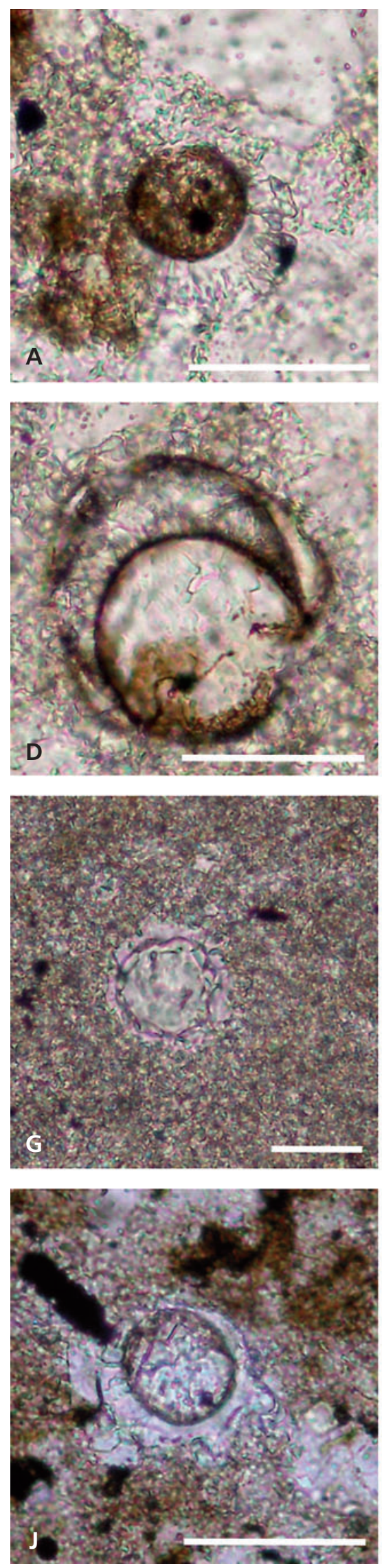
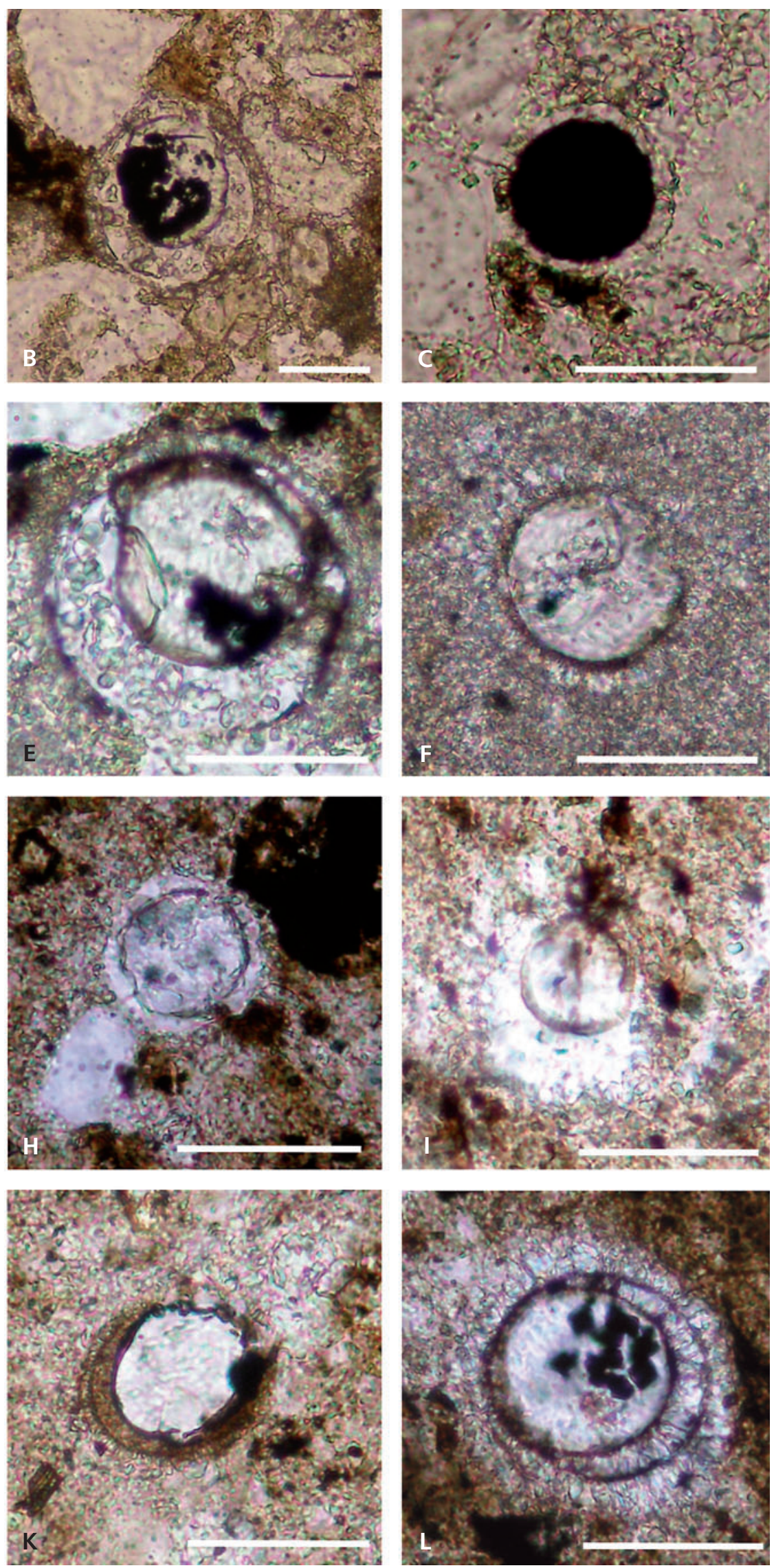
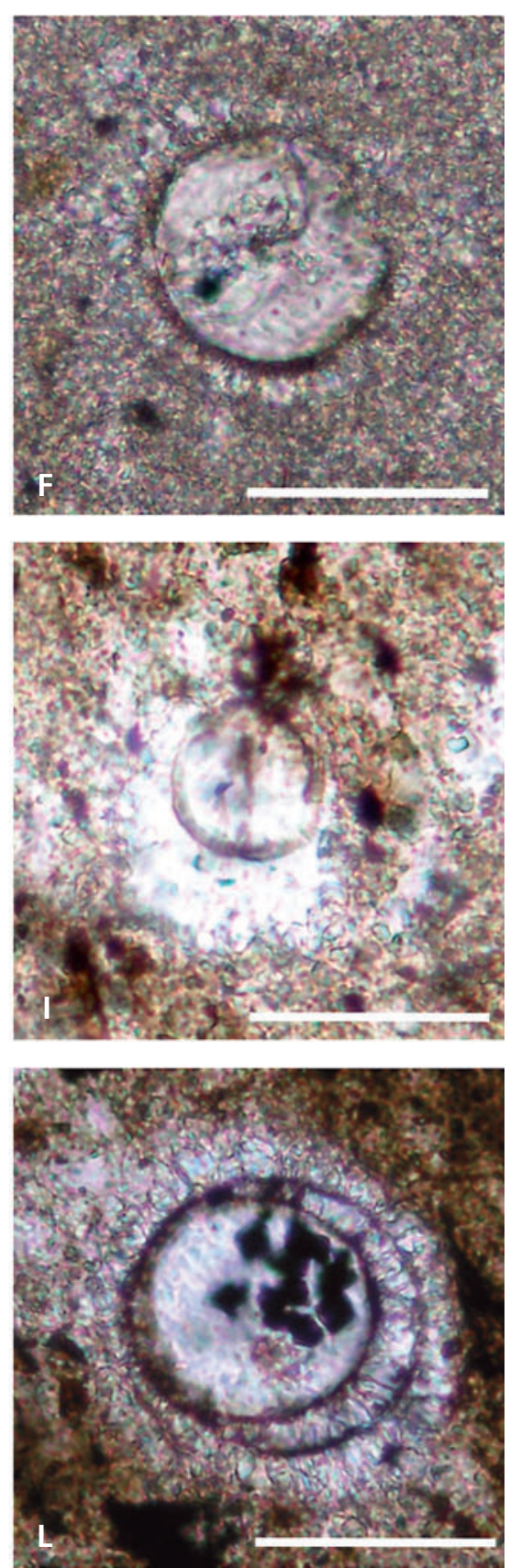
preserved Valanginian species Eiffellithus primus (OSA 12), Fig. 6E, E. windii (OSA 11, 12), Fig. 6D, E. striatus (OSA 12), Fig. 6F and segments of Micrantholithus speetonensis (OSA 9, 11) could be the result of redeposition. On the base of the presence of Rucinolithus terebrodentarius (OSA 2, 7, 12), Figs 6X, Y, Z, Rucinolithus windleyae Rutlege \& Bown (OSA 11), Fig. 6a and Calcicalathina oblongata (OSA 2, 7, 12), Fig. 6P, and the absence of Litraphidites bollii in studied samples indicate NC 5C Subzone interval (Bralower 1987, Bown et al. 1998), of the Latest Hauterivian through Early Barremian age.

\section{Calcareous dinoflagellates}

Calcareous beds within the investigated strata of the Hradiště Formation (comprised of bioturbated dark grey marly claystones, dark grey, sandy-marly claystones and dark claystones partially intermixed with fine-grained siltstone) were studied for the presence of calcareous dinoflagellates. Colomisphaera heliosphaera (Vogler), Fig. 7A, Colomisphaera conferta Řehánek (Figs 7F, 8B, F, G), Colomisphaera lucida Řehánek (Fig. 8H, I), Cadosina semiradiata olzae (Nowak), Fig. 7B, D, E, Cadosina semiradiata cieszynica (Nowak), Fig. 7K, Cadosina semiradiata semiradiata Wanner (Fig. 7L), Carpistomiosphaera valanginiana Borza (Fig. 8A), Stomiosphaera echinata Nowak (Figs 7I, J, 8C, D), Stomiosphaera wanneri Borza, Stomiosphaera sp. (Fig. 7C, $\mathrm{G}, \mathrm{H}$ ), Cadosinopsis nowaki Borza (Fig. 8E) have been determined.

Remnants of other organisms include tiny coalified fragments of plant tissues (Figs 9E, 10D), very few pollen grains, many pyritized radiolaria tests (Fig. 9A), foraminifers, with the later frequently silicified; (also is present microcrystalline quartz - "chalcedony"). Fragments of echinoderms (Fig. 9B, C) and ostracods (Fig. 9D) are not so frequent. Monaxone silicisponge spicules (Fig. 9F) and chitinous dinoflagellates are very rare. Radiolarians and sponges are mostly filled by calcite (Fig. 9A), radiolaria tests are also pyritized (Fig. 10F).

Other mineral components present are microcrystalline calcite, some detritic silt-sized quartz, pyrite (rarely occurring as framboids) and occasionally as larger aggregates (Fig. 10D), rarely with pressure rims (Fig. 10B). Sheets of muscovite and clay minerals, tiny yellowish carbonate rhombs (dolomite? siderite?), rare glauconite, few feldspars (chessboard-like albite), staurolite, zircon (Fig. 10F), rutile, blue authigenic tourmaline, tiny silicite fragments and a fragment of volcanic rock (Fig. 10C) are also present.

Diverse calcareous dinoflagellate associations mentioned above are typical for the Echinata Zone, placed into the Uppermost Valanginian to Early Aptian sediments by Lakova et al. (1999) and Reháková (2000).

\section{Non-calcareous dinoflagellates}

Samples taken from the Hradiště Formation contain predominantly black amorphous particles and less angular black and brown organic particles. Although non-calcareous dinoflagellates are visible in a few thin sections from the limestones of Sector B, it was not possible to find identifiable dinoflagellate cysts in any of the palynological samples.

Several poorly preserved dinoflagellate cysts were identified in the samples from the Lhoty Formation (samples Os16-20). These are representatives of a species with large stratigraphic range, such as Achomosphaera ramulifera (Deflandre) Evitt, Callaiosphaeridium asymmetricum (Deflandre \& Courteville) Davey \& Williams, Cribroperidinium orthoceras (Eisenack) Davey, Kleithriasphaeridium eoinodes (Eisenack) Davey, Oligosphaeridium complex (White) Davey \& Williams, Pterodinium cingulatum (O. Wetzel) Below, Spiniferites ramosus (Ehrenberg) Mantell. Two stratigraphically important species, Stephodinium coronatum Deflandre and Xiphophoridium alatum (Cookson \& Eisenack) Sarjeant are present in the formation. Upper Middle to lower Late Albian age can be assumed based on the first occurrences of S. coronatum, $X$. alatum and absence of species Lithosphaeridium siphoniphorum (Cookson \& Eisenack) Davey \& Williams and Palaeohystrichophora infusorioides Deflandre (Leereveld 1995, Stover et al. 1996). The common occurrence of L. siphoniphorum and P. infusorioides were observed at other locations of the Lhoty Formation in Silesian Unit only in the latest Albian (Skupien \& Vašíček 2002, Svobodová et al. 2004, Svobodová et al. 2011).

\section{Stratigraphy}

Sedimentary strata exposed from the thrust plane of the Silesian Nappe across the Subsilesian Nappe up the river belonging to several different stratigraphic formations. The lowest exposed part of the Silesian Nappe (in the direction of river flow) from the thrust plane to the beginning of the

Figure 8. Calcareous dinoflagellates. • A - Carpistomiosphaera valanginiana Borza; sample ODE. • B - Colomisphaera conferta Rehánek; sample ODF. • C, D - Stomiosphaera echinata Nowak; sample ODF. • E - Cadosinopsis nowaki Borza; sample ODH. • F, G - Colomisphaera conferta Řehánek; samples ODO. $\bullet \mathrm{H}$, I - Colomisphaera lucida Borza; sample ODO. $\bullet \mathrm{J}, \mathrm{K}-$ pyritized tests of radiolarians; sample ODP. Scale bar $=100 \mu \mathrm{m}$. 

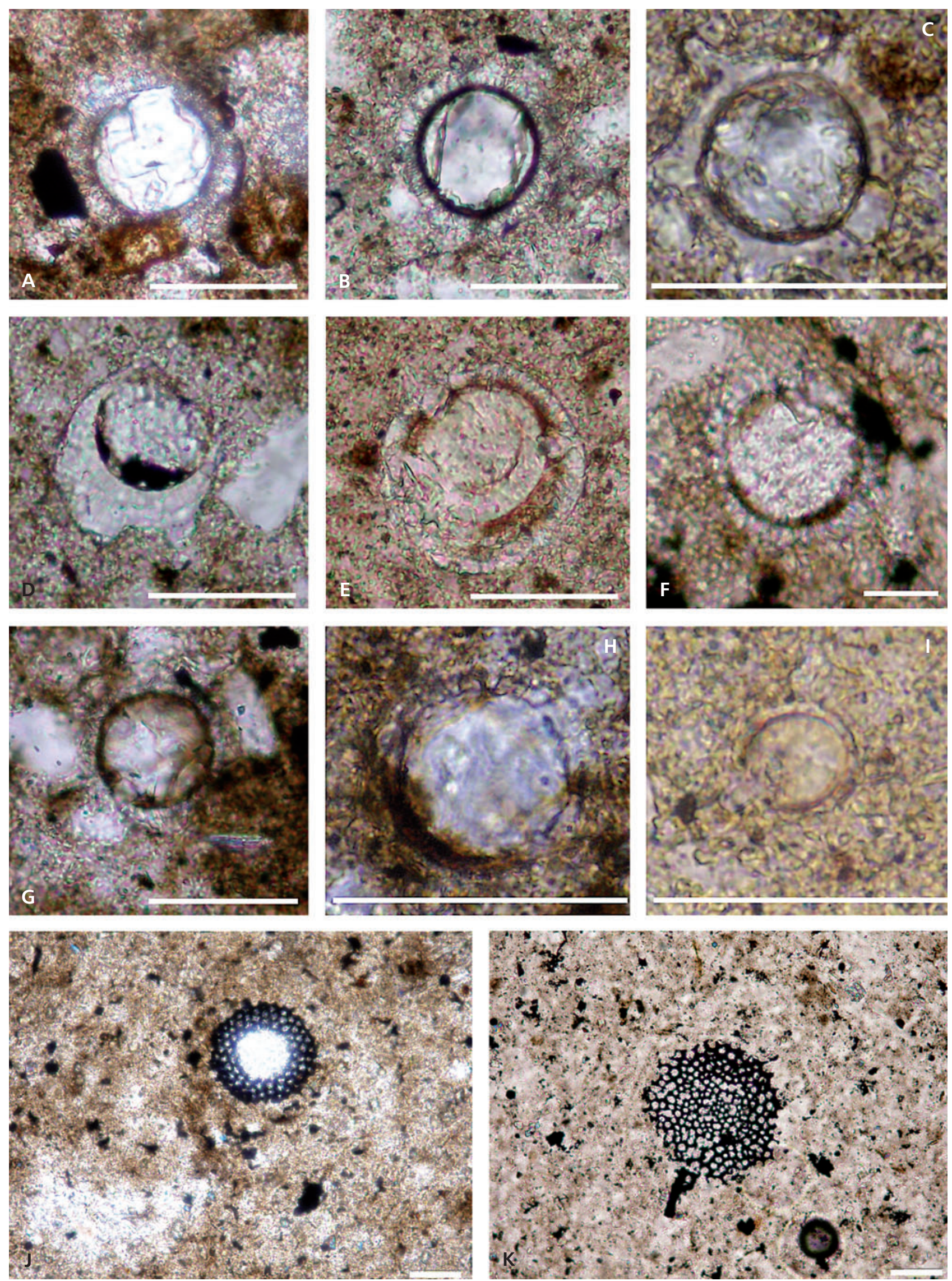
river rapids (Sector A) belongs to the Hradiště Formation. On the basis of the presence of calcareous nannofossils with Rucinolithus terebrodentarius and Calacicalathina oblongata in samples OSA 2, 7, 12 and the absence of Litraphidites bollii, in examined samples, the flyschoid complex of platy to thin-bedded sandstones, intercalated with grey calcareous claystones, belongs to the assemblage of the NC 5C Subzone interval of Latest Hauterivian to Early Barremian age (Bralower 1987, Bown et al. 1998).

The following part of the Hradiště Formation (Sector B), from the beginning of the rapids up to the end of the continuous section up the river, is characterized by occurrence of rhythmically alternating, pale grey, thin pelagic limestones, locally intercalated with sandstones. In the uppermost part of this section, the limestones disappear and the section ends with a complex of multiple alternating calcareous claystones and platy sandstones. Calcareous nannofossils with Cruciellipsis cuvillieri, Rucinolithus terebrodentarius, $R$. windleye, Speetonia colligata, Calcicalathina oblongata, Litraphidites bollii in studied samples ODE to ODN suggest the Late Hauterivian NC 5A, NC 5B Subzones (Bralower 1987, Bown et al. 1998). Sample ODO yields a different nannofossil assemblage with boreal Hauterivian affinity (BC 9 - Švábenická 2008) according to the presence of Crucibiscutum salebrosum, Tegulalithus septentrionalis and nannoconids - Nannoconus abundans?, N. inornatus?, N. ssp.

Lithologically, the sediments exposed at the Ostravice (Sector B) locality are very similar to those exposed in an abandoned quarry in Nová Dědina, located on the left bank of the Čeladenka River. The above-mentioned quarry was selected by Roth et al. (1962) as the type section for the Těšín-Hradiště Formation. However, the authors did not mention the presence of any limestones. Lithology and nannofossils of the deposits outcropping in this quarry were recently studied by Skupien et al. (2003). The latter authors proposed this quarry as the type locality for the revised Hradiště Formation (in accordance with the international rules for the definition of lithostratigraphical units). Švábenická (in Skupien et al. 2003) stated that in a poorly preserved calcareous nannoplankton assemblage in the limestones prevail long-ranging species, among them Cruciellipsis cuvilieri she suggested that the strata range stratigraphically from the Late Berriasian to Late Hauterivian (lower part).

In the quarry in Nová Dědina as well as in the studied section at the Ostravice River, the base of the calcareous beds of the Hradiště Formation is not exposed. In the Ostravice Section, the lower part of the Hradiště Formation without limestones (Sector A) is in tectonic contact with the segment with limestone intercalations (Sector B). A segment of the Hradiště Formation with pelagic limestones very probably represents a separate lithostratigraphic member of the Formation. It could be consid- ered a new member in the middle part of the Hradiště Formation, named the Čeladenka Member (after the Čeladenka River), where a similar development was also documented (Skupien et al. 2003).

After the interruption of an outcrop (about $13 \mathrm{~m}$ ), on the right river bank black-grey, compact, non-calcareous claystone, with chip-like disintegration is exposed (Sector C). It encloses clayey ironstones. Approximately $5.5 \mathrm{~m}$ of exposed strata was documented in detail by Kratochvílová et al. (2003), as the strata were sampled for Corg content. These deposits lithologically correspond to the Verovice Formation, and represent typical Upper Aptian strata development in the Silesian Unit. But they did not yield any biostratigraphic data. The Corg study by Kratochvílová et al. (2003) found that the Corg content in the outcropping segment of Veřovice Formation is low, with a maximum value in one sample of $1.75 \%$.

From the last occurrences of the Hradiště Formation (Upper Hauterivian) in the Ostravice River it is evident that between the last outcrops of the Hradiště Formation and those of the Veřovice Formation, a substantial part of the Hradiště Formation belonging to the entire Barremian and Lower Aptian sequence is missing.

After the small outcrop of Veřovice Formation, a large outcrop of pelitic, non-calcareous or slightly calcareous, locally spotted claystones follow (Sector D). Their lithology corresponds to the Lhoty Formation (Albian). In the claystones, non-calcareous dinoflagellates (Pterodinium cingulatum, Stephodinium coronatum, Xiphophoridium alatum) are present, indicating Middle to lower Late Albian age of the strata (Skupien 1999).

After a rather long interruption in the outcrops at both banks of the Ostravice River, the strata again outcrop on the left bank of the river (Sector E). Beginning at the southern margin of the football playground at the municipality of Ostravice, a belt of subhorizontally layered, dark grey, only slightly calcareous and non-calcareous claystones with large clayey ironstone nodules is cropping out. According to scarce findings of deshayesitid ammonites (Paradeshayesites weissiformis - cf. Vašíček et al. 2004 and $P$. semenovi - $c f$. Vašíček 2008), these strata were dated as Early Aptian in age. They belong to the uppermost part of the Hradiště Formation.

\section{Conclusions}

The Lower Cretaceous sequences of the Silesian Nappe under study and their continuation up the river was divided into five sectors.

1. The first sequence (Sector A), from the Silesian Nappe thrust plane up to the rapids, is structurally complex due to tectonics, thus the section cannot be reconstructed with 

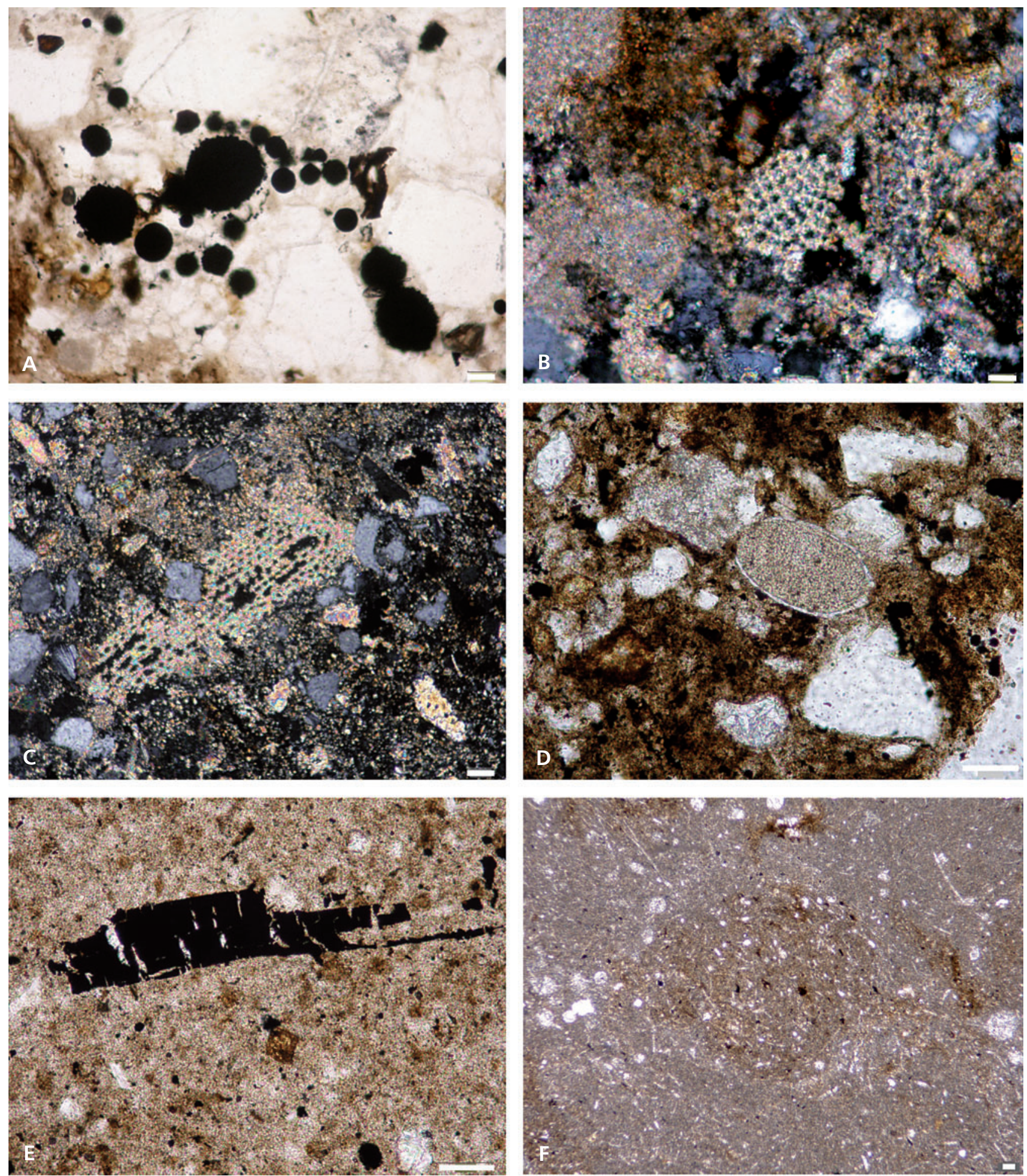

Figure 9. Thin sections. $\bullet \mathrm{A}$ - accumulation of pyritized tests of radiolarians in siltstone; sample ODO. $\bullet \mathrm{B}, \mathrm{C}-$ fragments of echinoderms in siltstone; sample ODO. $\bullet$ D - ostracoda in bioturbated siltstone; sample ODC1. $\bullet$ - fragments of coalified plant tissue remnants in calcareous marlstone; sample ODH. $\bullet \mathrm{F}$ - irregular accumulation of sponge spicules; the sediment was probably stirred by bioturbation; sample ODD. Scale bar $=100 \mu \mathrm{m}$. 

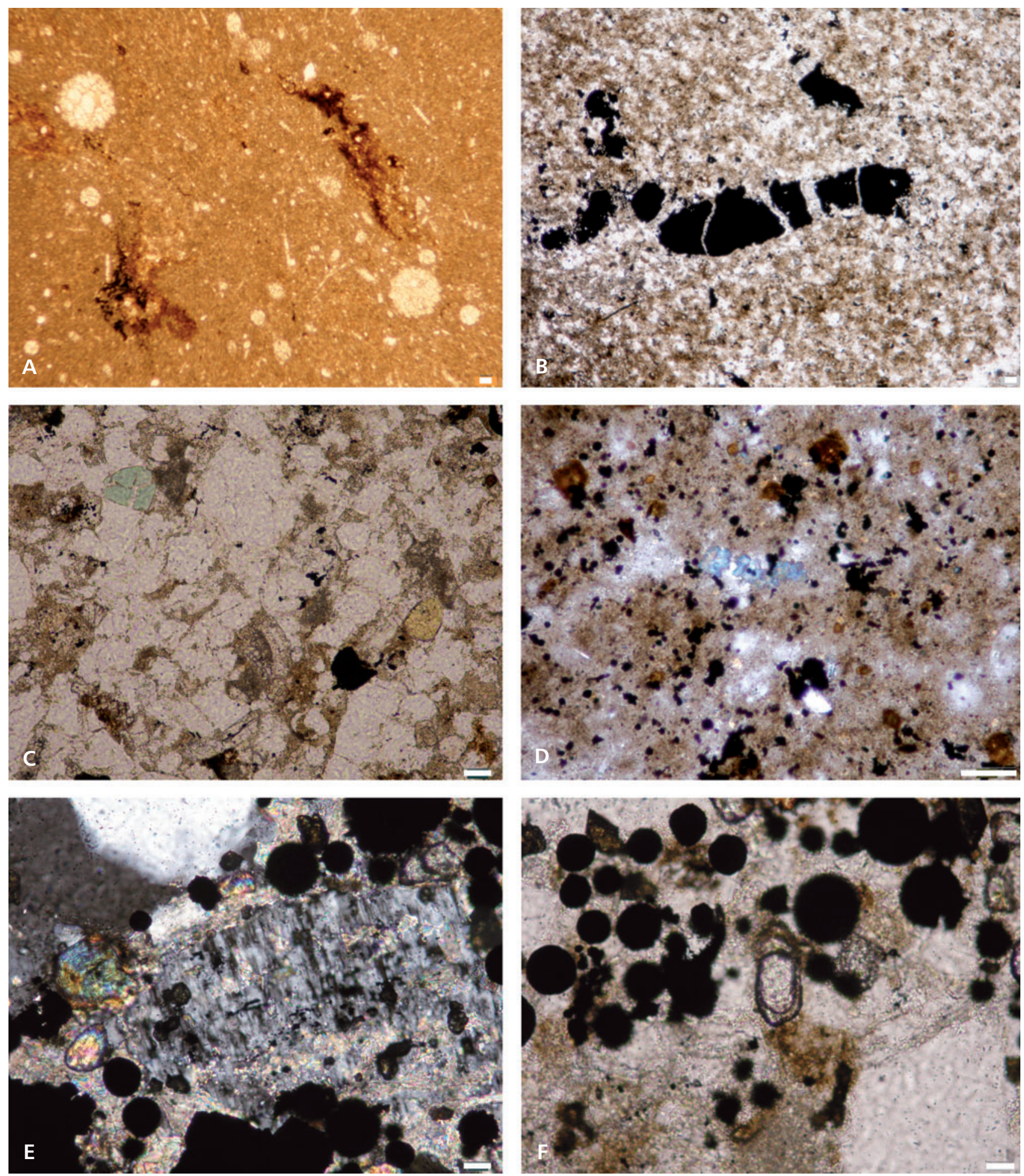

Figure 10. Thin sections. $\bullet \mathrm{A}$ - calcified sponges and radiolarian tests filled by calcite. Radiolaria-sponge microfacies in micritic marly limestone; sample ODD. $\bullet$ B - pyrite aggregates are disintegrated by pressure to smaller particles surrounded by pressure rims. Marlstone; sample ODE. $\bullet$ C - fragments of micrite limestone and clasts of volcanics in shaly bioturbated siltstone matrix comprised by silty dertitic quartz grains; sample ODC1. $\bullet D-$ accumulations of pyrite and tiny fragments of chared plants tissue in carbonate claystone; sample ODM. $\bullet \mathrm{E}$ - chessboard-like albite in the siltstone; sample ODO. - $\mathrm{F}$ - pyrite agregates (probably pyritized tests of radiolarians), and zircon grains in siltstone; sample ODO. Scale bar $=100 \mu \mathrm{m}$. 
confidence. Some claystone samples from this section yielded poorly preserved remnants of calcareous nannofossils, which according to the presence of Rucinolithus terebrodentarius and Calcicalathina oblongata among other nannofossils and the absence of Litraphidites bollii indicate the latest Hauterivian to the Early Barremian age of the strata.

2. The contact between the first and the second lithological sequence (Sector B) is tectonic. Intercalated pelagic limestones contain richer calcareous nannofossil assemblage than was found in the first sequence. Stratigraphically indicative species belong to Calcicalathina oblongata, Cruciellipsis cuvillieri, Litraphidites bollii, Rucinolithus terebrodentarius, $R$. windleyae and Speetonia colligata, which confirm the Late Hauterivian age. The sample from the uppermost part of Sector B containes rare nannoconids that are, together with Crucibiscutum salebrosum and Tegulalithus septentrionalis, typical of boreal realm!

3. The pelagic micritic limestones present in the succession of the strata of the Hradište Formation were recorded on this locality and in the whole Hradiště Formation for the first time. Rare calcareous nannofossils from the calcareous claystones below the rapids and from the micritic limestones in and above the rapids, allowed for the first time relatively precise dating of Lower Cretaceous sediments of the lower part of the Hradiště Formation, as Late Hauterivian (Sector A) and latest Hauterivian to Early Barremian (Sector B) in age.

4. The limestones and calcareous claystones also contain a rich assemblage of calcareous dinoflagellates of a wider stratigraphic span (the uppermost Valanginian to Barremian).

5. Limestone layers slowly disappear in the uppermost part of the continuous outcrops of the Hradiště Formation (Sector B). The last metres of outcropped Upper Hauterivian sediments are free of limestones.

6. From the lithological composition of the strata, the presence of pelagic sediments and micritic limestones within the Hradiště Formation deposition of sediments occurred in the ocean basin, above the CCD (carbonate dissolution level). Incorporation of quartz silt in the limestones proves that deposition took place most probably on the continental margin, or in its vicinity. The embedded sandstones showing upward grain size gradation are clearly of turbiditic origin. Their composition is dominated by plutonic quartz transported from the shelf area, as indicated by incorporated bioclasts.

7. The presence of limestone intraclasts in gravel sand- stones documents erosion of the Upper Jurassic to early Lower Cretaceous carbonate platform by turbiditic currents.

8. The third lithologic sequence (Sector C) is different from the previous two. The non-calcareous pelagic claystones enclosing iron nodules belong to the Verovice Formation. They lack any fossils or microfossils except of scarce pyritized radiolarians. According to the analogy with other localities of the Silesian Unit, the Veřovice Formation is of Late Aptian age. The stratigraphic data unambiguously indicate tectonic contact between the Hradiště and Veřovice formations. A substantial part of the Hradiště Formation, corresponding to the Barremian-Early Aptian, is missing at this locality.

9. After a rather long interruption of strata exposed up the river above the protected natural monument, a large section of sedimentary strata is exposed on the right, undercutslope bank of the Ostravice River, at the level of the south edge of football playground at the municipality of Ostravice (Sector $\mathrm{D}$ ). These deposits belong to the stratigraphically youngest lithostratigraphical formation - the Lhoty Formation, but they did not yield any determinable calcareous microfauna, or macrofauna. According to the analogy with other localities of the Silesian Unit and according to non-calcareous dinoflagellates found in the strata, their age is Middle to the lower part of Late Albian.

10. The last outcrop up the river (Sector E) belongs to the uppermost part of the Hradiště Formation. Its age is not documented by microfossils (as none have been found), but a scarce finding of an ammonite suggests Early Aptian age.

11. The described succession documents very complex tectonic and stratigraphic architecture of relatively monotonous pelagic deposits of the Silesian Nappe at the vicinity of a major overthrust plane in the Moravskoslezské Beskydy Mountains.

\section{Acknowledgements}

We thank to the management of the Institute of Geonics of the Academy of Sciences of the Czech Republic for the long-termed moral support leading to the realization of this contribution. The Czech authors thank for the financial support from the former project GAČR No. 205/05/0985. Slovakian colleagues were supported by the APVV/0280-07 and LPP 0120/09 projects; radiolarian associations were discussed with $\mathrm{M}$. Smrečková. The authors also thank to V. Šimo for the determination of ichnofossil and O. Malek for the extending of his two field photos. We would like to thank M.A. Gasiński and an anonymous reviewer for careful reading the manuscript; their critical remarks significantly improved the manuscript. 


\section{References}

Boorová, D., Jansa, L., MatÝsek, D., Skupien, P. \& VAŠ̌́̌̌EK, Z. 2008. Příspěvek k litologii křídových souvrství na profilu Bystrý potok u Trojanovic (slezská jednotka, Vnějšś Západní Karpaty, Česká republika). Acta Musei Moraviae, Scientiae geologorum 83, 185-217. [in Czech with English abstract]

BorZA, K. 1984. Cadosinopsis nowaki n. sp. (incertae sedis) from the Lower Cretaceous of the West Carpathians. Geologicky zborník Geologica Carpathica 35(5), 649-661.

Bown, P.R., Rutledge, D.C., Crux, J.A. \& Gallagher, L.T. 1998. Lower Cretaceous, 86-131. In Bown, P.R. (ed.) Calcareous nannofossil biostratigraphy. Chapman \& Hall, London.

Bown, P.R. \& Young, J.R. 1998. Introduction, 34-85. In Bown, P.R. (ed.) Calcareous nannofossil biostratigraphy. Chapman \& Hall, London.

Bralower, T.J. 1987. Valanginian to Aptian calcareous nannofossil stratigraphy and correlation with the upper M-sequence magnetic anomalies. Marine Micropaleontology 11, 293-310. DOI 10.1016/0377-8398(87)90003-X

Channell, J.E.T., Cecca, F. \& ERBA, E. 1995. Correlations of Hauterivian and Barremian (Early Cretaceous) stage boundaries to polarity chrons. Earth and Planetary Science Letters 134, 125-140. DOI 10.1016/0012-821X(95)00111-O

ELIÁš, M. 1970. Litologie a sedimentologie slezské jednotky v Moravskoslezských Beskydách. Sborník geologických věd, $\check{R} a d a$ G-Geologie 18,7-99. [in Czech with English summary]

EliÁŠ, M. 1973. Guide to Excursion I: Sedimentological excursion; 15. Ostravice, 43-44. Guide to Excursion I. X Congress of Carpathian-Balkan Geological Association. GÚDŠ, Bratislava.

Eliáš, M., Dvořák, J., Elíśšová, H., Pesl, V. \& ŠMíd, B. 1979. Průvodce k exkurzi do moravského paleozoika a karpatského flyše, pořádané v rámci oslav 60. výročí založení Ústředního ústavu geologického Praha; 11. Ostravice, 14. Pobočka České vědeckotechnické společnosti v Ústředním ústavu geologickém, Praha. [in Czech]

EliÁš, M., Skupien, P. \& VAŠÍČEK, Z. 2003. Návrh úpravy litostratigrafického členění nižší části slezské jednotky na českém území (vnější Západní Karpaty). Sborník vědeckých prací Vysoké školy báňské - Technická univerzita Ostrava, Řada hornicko-geologická 49, Monografie 8, 7-13. [in Czech with English summary]

Foldyna, J. 1964. Př́ičné vrásové struktury v godulském př́krovu. Habilitation thesis, Vysoká škola báňská, Ostrava. [in Czech]

Gába, Z., Hladilová, Š., HouZar, S., Skupien, P., VAŠİ̌čer, Z. \& ZiEGLER, V. 2002. Geologické vycházky Českou republikou. Vycházka č. 193: K peřejím řeky Ostravice u obce Ostravice, 429-431. Univerzita Karlova, Nakladatelství Karolinum, Praha. [in Czech]

Halásová, E., Jansa, L., Reháková, D., Skupien, P. \& VAšíččer, Z. 2009. New biostratigraphic data from Ostravice River channel reservation (Outer Western Carpathians). Mineralia Slovaca - Geovestnik 40(2008, 3-4), 235-236.

Kratochvílová, L., Dolejšová, M., Skupien, P. \& VAšíčeK, Z. 2003. Obsahy organického uhlíku v nejvyšší části hradišțského souvrství a ve veřovickém souvrství (svrchní apt, vnější Západní Karpaty, Česká republika). Sborník vědeckých prací Vysoké školy báňské - Technická univerzita Ostrava, Řada hornicko-geologická 49, Monografie 8, 53-64. [in Czech with English summary]

Krejčí, O., Eliáš, M., Švábenická, L. \& Martinec, P. 2002. Western Carpathians in the territory of the Czech Republic. Stop 7.4: Ostravice - rapids; Frýdlant tectonic window (southern margin), 100. In VoZÁr, J., VoJTKo, R. \& Sliva, L. Guide to Geological Excursions. XVII ${ }^{\text {th }}$ Congress of CarpathianBalkan Geological Association. Bratislava.

Lakova, I., Stoykova, K. \& Ivanova, D. 1999. Calpionellid, nannofossils and calcareous dinocyst bioevents and integrated biochronology of the Tithonian to Valanginian in the West Balkanides, Bulgaria. Geologica Carpathica 50(2), 151-168.

LEEREVELD, H. 1995. Dinoflagellate cysts from the Lower Cretaceous Río Argos succession (SE Spain). Laboratory of Palaeobotany and Palynology, Contribution Serie 2, 1-175.

MENČí, E. 1967. Contact between the Bohemian Massif and the Carpathians; 9. Ostravice (river bed) - the thrust of the Silesian over Subsilesian nappe, 18-19. Guide to Excursion 14 AC, Czechoslovakia. International Geological Congress, XXIII Session, Prague 1968. Ústřední ústav geologický in Academia, Praha.

MenČí, E. 1973. Contact of the Bohemian Massif and the West Carpathians Mts. 4. Ostravice (river bed), 15-17. Guide to Excursion B. X Congress of Carpathian-Balkan Geological Association. GÚDS̆, Bratislava.

REHÁKOVÁ, D. 2000. Evolution and distribution of the Late Jurassic and Early Cretaceous calcareous dinoflagellates recorded in the Western Carpathian pelagic carbonate facies. Mineralia Slovaca 32, 79-88.

Rотн, P.H. 1978. Cretaceous nannoplankton biostratigraphy and oceanography of the northwestern Atlantic Ocean, 731-759. In BENSON, W.E., SHERIDAN, R.E. et al. Initial Reports of Deep Sea Drilling Project 44. U.S. Government Printing Office, Washington. DOI 10.2973/dsdp.proc.44.134.1978

Roth, P.H. 1983. Jurassic and Lower Cretaceous calcareous nannofossils in the western North Atlantic (Site 534): biostratigraphy, preservation, and some observations on biogeography and paleoceanography, 587-621. In SHERIDAN, R.E., Gradstein, F.M. et al. Initial Reports of Deep Sea Drilling Project 76. U.S. Government Printing Office, Washington. DOI 10.2973/dsdp.proc.76.125.1983

Rотн, Z. 1967. Unmetamorphosed sedimentary formations of Czechoslovakia; 21. Ostravice - the contact of the Silesian and the Ždánice-Subsilesian nappes, 28-30. Guide to Excursion 2 AC, Czechoslovakia. International Geological Congress, XXIII Session, Prague 1968. Ústřední ústav geologický in Academia, Praha.

Rотн, Z. et al. 1962. Vysvětlivky k přehledné geologické mapě ČSSR 1 : 200 000, M-34-XIX, Ostrava, p. 117. Geofond in NČSAV, Praha. [in Czech]

SKuPIEN, P. 1999. Noncalcareous dinoflagellates of the Lower Cretaceous sediments of the Godula Development of the Silesian Unit. 202 pp. Ph.D. thesis, VŠB - TU Ostrava. [in Czech]

SKuPIEN, P. \& VAŠíčEK, Z. 2002. Lower Cretaceous ammonite and dinocyst biostratigraphy and paleoenvironment of the Silesian Basin (Outer Western Carpathians). Geologica Carpathica 53(3), 179-189.

Skupien, P., Vaší̌cek, Z. \& Švábenická, L. 2003. Typový profil 
hradištského souvrství v Nové Dědině u Frýdlantu n. O. (slezská jednotka, Vnější Západní Karpaty, Česká republika). Sborník vědeckých prací Vysoké školy báňské - Technické

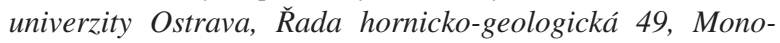
grafie 8, 45-52. [in Czech with English summary]

Stover, L.E., Brinkhuis, H., Damassa, S.P., De Verteuil, L., Helby, R.J., Monteil, E., Partridge, A.D., Powell, A.J., Riding, J.B., Smelror, M. \& Williams, G.L. 1996. Chapter 19. Mesozoic-Tertiary dinoflagellates, acritarchs and prasinophytes, 641-750. In Jansonius, J. \& McGregor, D.C. (eds) Palynology: principles and applications. American Association of Stratigraphic Palynologists Foundation, Salt Lake City.

Svobodová, M., Hradecká, L., Skupien, P. \& Švábenická, L. 2004. Microfossils of the Albian and Cenomanian shales from the Štramberk area (Silesian unit, Outer Western Carpathians, Czech Republic). Geologica Carpathica 55(5), 371-388.

Svobodová, M., Švábenická, L., Skupien, P. \& Hradecká, L. 2011. Biostratigraphy and paleoecology of the Lower Cretaceous sediments in the Outer Western Carpathians (Silesian Unit, Czech Republic). Geologica Carpathica 62(4), 309-332. DOI 10.2478/v10096-011-0024-9
ŠVÁBENICKÁ, L. 2008. Biostratigrafie spodnokřídových sedimentů slezské jednotky na základě studia vápnitých nanofosilií (flyšové pásmo Západních Karpat, Česká republika). Zprávy o geologických výzkumech v roce 2007, 63-72. [in Czech]

VAŠIČEK, Z. 2008. Barremian and Early Aptian ammonites from the Godula Facies of the Silesian Unit in the Outer Western Carpathians, Czech Republic. Acta Geologica Polonica 58(4), 407-423.

VAŠIČEK, Z. 1994. Locality No. 17 Ostravice, near Frýdlant, 55-57. In MichalíK, J. \& ReHÁKovÁ, D. Field trip guide: Stratigraphy, sedimentology and paleogeography of Cretaceous sequences in western part of the Western Carpathians. Annual Assembly IGCP Project No. 362, Tethyan and Boreal Cretaceous, October 1994, Smolenice. GI SAS, Department of Geology of Comenius University, Bratislava.

VAŠIČEK, Z., SKuPIEN, P. \& ŠUlgan, F. 2004. New occurrences of Lower Cretaceous ammonites in the western part of the Silesian Unit (Barremian - early Aptian, Outer Western Carpathians, Czech Republic). Journal of Czech Geological Society 49(1-2), 41-55.

\section{Appendix}

\section{Micropaleontological samples}

\section{Hradiště Formation}

OSA 2. Claystone containing coalified plant tissues and infrequent pyritized debris. Dominant is Watznaueria barnesae, Cyclagelosphaera margerelii. Calcicalathina oblongata, Cretarhabdus conicus, Diazomatholithus lehmanii, Discorhabdus ignotus, Helenea chiastia, Litraphidites carniolensis, Retecapsa angustiforata, Speetonia colligata?, Tubodiscus verenae?, T. jurapelagicus, Rucinolithus terebrodentarius, Staurolithes crux, Zeugrhabdotus embergeri, Z. spp. are present. No nannoconids and determinable rests of coccoliths occur. Age: Latest Hauterivian-Early Barremian.

OSA 3. Claystone, containing coalified plant tissues (partly pyritized) and a pollen grain. Abundant Cyclagelosphaera margerelii, Watznaueria barnesae, Discorhabdus ignotus, Zeugrhabdotus spp. A lot of undeterminable rests of heterococcoliths.

OSA 4. Dark claystone, partly intermixed with fine-grained siltstone. The intermixing was probably caused by limnivorous animals. Very fine-grained silt quartz of $0.06 \mathrm{~mm}$ in diammeter, and calcite grains are present. Calcite veinlets with prismatic texture, pyrite pigment, rare tiny scales of clay minerals also occur. Nannofossils Watznaueria barnesae, W. manivitae.

OSA 5/I. Dark-grey claystone with ostracod valves. Clay minerals are dominant, less are tiny dolomitic rhombs. Pyrite in irregular aggregates and within remnants of plant tissues is common. Rare is also brown, non-coalified plant detritus, 2 acritarchs, 2 damaged pollen grains, and rare are very tiny fragments of hydromicas. Cyclagelosphaera margerelii, Zeugrhabdotus embergeri, Watznaueria barnesae, Zeugrhabdotus spp.

OSA 5/II. Dark-grey claystone. Clay minerals are dominant. Tiny dolomitic rhombs are in minority. Pyrite in irregular aggregates and in the remnants of plant tissues is common. Non-coalified plant detritus, damaged pollen grains, and very tiny fragments of hydromicas are rare. One chlorite sheet is present. Quartz silt present in trace amount is $0.04 \mathrm{~mm}$ in size.

OSA 6. Dark claystone. Clay minerals, rare fine silty quartz up to $0.07 \mathrm{~mm}$ in size, and two patches of fine-grained sand result of bioturbation. Coalified plant detritus (disintegrated to individual cells), some pyritized. Cyclagelosphaera margerelii, Cretarhabdus?, Watznaueria barnesae, Zeugrhabdotus embergeri, Zeugrhabdotus spp.

OSA 7. Black claystone (marly?) with minor coalified plant detritus, some pyritized. Common are tiny calcite rhombs, probably calcite and calcite veinlet formed by fibrous calcite. Assipetra infracretacea, Calcicalathina oblongata?, Cretarhabdus conicus?, Cyclagelosphaera margerelii, Diazomatholithus lehmanii, Discorhabdus ignotus, Micrantholithus hoschulzii, Rhagodiscus asper, Rucinolithus terebrodentarius, Tubodiscus jurapelagicus, Watznaueria barnesae, Zeugrhabdotus embergeri, Zeugrhabdotus spp. Age: Latest Hauterivian-Early Barremian.

OSA 8. Dark-grey sandy-marly claystone. Clay minerals are dominant, less of silty quartz. Five simple cysts of Stomiosphaera echinata Nowak, which are mostly silicified, and fragment of foraminifera are also present. Very rare is Watznaueria barnesae.

OSA 9. Dark-grey marly-claystone, comprised by clay minerals and very rare silty quartz. Common is coalified plant detritus, which is pyritized (commonly the coalification caused disintegrating to the individual cells). Pyrite, few scales of chlorite and imperfectly preserved 
calcareous cysts are rare. Abundant is Watznaueria barnesae. W. manivitae, Discorhabdus ignotus, Eiffelithus windii?, Percivalia fenestrata?, Micrantholithus speetonensis?, Diazomatholithus lehmanii, Zeugrhabdotus embergeri, Helenea chiastia, Retecapsa angustiforata, Cyclagelosphaera margerelii are present and many undeterminable rests of coccoliths.

OSA 10. Dark-grey claystone. Brownish clay minerals with trace amount of fine-grained quartz. Carbonate rhombs (probably dolomite), pyritized coalified plant remnants, rare globular pyrite and demaged pollen grain, two simple cysts of Colomisphaera conferta, and few chitinous foraminiferal membranes are also present. Dominant is Watznaueria barnesae. Others nannofossils Assipetra infracretacea, Crucibiscutum salebrosum, Cyclagelosphaera margerelii, Cretarhabdus striatus, Diazomatholithus lehmanii, Helenea chiastia, Litraphidites carniolensis, Micrantholithus hoschulzii, Nannoconus spp.?, Percivalia fenestrata, Retecapsa angustiforata also are present.

OSA 11. Dark-grey, sandy-marly claystone comprised by brownish clay with calcite, forming micritic aggregates. Fine-grained quartz sand is up to $0.15 \mathrm{~mm}$ in size. Zircon, chlorite, muscovite, pyritized radiolarians, echinoderm particle, echnoid spines, fragment of thin-shelled bivalve, and silicified cysts of Cadosina semiradiata olzae, Cadosina semiradiata cieszynica, Stomiosphaera echinata occur. One of them is three-layered - ?Cadosinopsis nowaki. Pyrite is present in coalified plant remnants, rarely globular, tiny dolomite rhombs also occur. Watznaueria barnesae is dominant, common are Cyclagelosphaera margerelii, Zeugrhabdotus spp., Assipetra infracretacea, Diazomatholithus lehmanii, Discorhabdus ignotus, Eiffelithus windii?, Micrantolithus hoschulzii, M. speetonensis - segments, Rhagodiscus asper, Rhagodiscus dekaenelii, Rotelapillus laffitei, Rucinolithus windleye, Tubodiscus spp., Tubodiscus jurapelagicus, T. verenae? Age: Late Hauterivian.

OSA 12. Dark-grey, sandy-marly claystone. Micritic aggregates are comprised of brownish clay with calcite. It contains detritic quartz of fine-grained sand, chlorite scales and rare muscovite scales. Pyritized radiolarians, echinoderm fragments, thin-shelled bivalves, and rare cysts of Cadosina semiradiata olzae, Cadosina semiradiata cieszynic, Stomiosphaera echinata and Cadosinopsis nowaki are sporadic. Pyrite is in coalified plant remnants, rarely globular in the matrix. Nanno association: Assipetra infracretacea, Calcicalathina oblongata, Cretarhabdus striatus, Diazomatholithus lehmanii, Eiffelithus primus, E. windii, E. striatus, Helenea chiastia, Rotelapillus laffitei, Micrantholithus hoschulzii, Rucinolithus terebrodentarius, Tubodiscus jurapelagicus, T. verenae, Tubodiscus spp., Watznaueria barnesae. Many undeterminable rests of nannofossils are present. Age: Latest Hauterivian-Early Barremian.

ODA. Dark-grey calcareous claystone - carbonate is comprised by microcrystalline calcite. Pyritized radiolarians, ghosts of foraminifers replaced partially by pyrite, fragments of coalified plant tissues are rare. Small, brown, faintly limited patches belong most probably to worm burrows (fucoids). The rock is rich in pyrite aggregates and clusters of framboidal pyrite. The silty quartz grains are often angular; with average size about $0.07 \mathrm{~mm}$. The matrix contains also Fe-calcite rhombs and tiny glauconite grains. Watznaueria barnesae, Cyclagelosphaera margerelii are present.

ODB. Dark-grey calcareous marlstone. Matrix is mixture of clay minerals and microcrystalline calcite. Quartz replaced radiolarians are rare, numerous are fucoids with diameter of about $0.4 \mathrm{~mm}$. Angular silt quartz grains are also present, together with pyrite aggregates (also clusters of framboidal pyrite). The pyrite aggregates are often arranged as filaments - probably replacing plant filaments. Watznaueriaceae (Watznaueria barnesae, Cyclagelosphaera margerelii, Cretarhabdus conicus, Zeugrhabdotus embergeri) are abundant and many rests of nannofossils.

ODC 1. Dark-grey calcareous, bioturbated siltstone. Quartz silt dominates over the calcite grains. The rock contains tiny radiolarian tests (locally pyritized), fragments of benthic foraminifers, ostracoda, and a fragment of echinoid spine. From calcareous dinoflagellates $C o$ lomisphaera heliosphaera, Cadosina semiradiata olzae and Stomiosphaera sp. are present. Micritic limestone debris occur in trace amount, volcanics, staurolite, zircon, chessboard-like albite grains, mica scales and glauconite, Fe-calcite (or siderite) rhombs were observed, too. The rock is penetrated by thin calcite veinlets.

ODC 2. Dark-grey, bioturbated calcareous marlstone, coarser grained than ODC 1, due to richer silty quartz admixture. Watznaueria barnesae is abundant, Cyclagelosphaera margerelii, Assipetra infracretacea, Cretarhabdus conicus, Micrantholithus hoschulzii are common.

ODD. Grey, spotted, marly micritic limestone. It contains numerous cross-sections of calcified sponge spicules. Pores in radiolarians are filled with calcite, rarely by pyrite. Monaxone sponge spicules are unoriented suggesting that the sediment texture was stirred by bioturbation. Trace fossils (fucoids) are present. Calcareous dinoflagellate cysts Colomisphaera conferta, Stomiosphaera cf. wanneri are rare. Larger quartz grains, pyrite aggregates, framboidal pyrite clusters and also spheres are scattered in the matrix. Assipetra infracretacea, Watznaueria barnesae, Zeugrhabdotus embergeri are present.

ODE. Dark-grey marlstone. The rock contains calcareous dinoflagellates Stomiosphaera echinata (tabulate forms, cooling); Stomiosphaera wanneri, Cadosina semiradiata cieszynica, Cadosina semiradiata semiradiata, Carpistomiosphaera valanginiana. Common is also coalified plant detritus (most probably tissues), pyrite, detritic silty quartz and mica scales. Watznaueria barnesae is abundant. Others nannofossil species present are: Calcicalathina oblongata, Cretarhabdus conicus, Cruciellipsis cuvillieri, Zeugrhabdotus diplogrammus, Z. embergeri, Conusphaera rothii, segments of Micrantholithus spp.

ODF. Dark-grey marlstone comprised by microcrystalline calcite and clay minerals. Rare dinoflagellates are: Colomisphaera conferta, Stomiosphaera echinata, fragments of plant tissues and pollen grains. The rock contains silt size quartz grains admixture (grains up to $0.06 \mathrm{~mm}$ in size) and rhombs of authigenic carbonates (?dolomite), up to $0.04 \mathrm{~mm}$ in size. Rare glauconite grains are present, too. Pyrite grains were fractured with fractures filled with fibrous calcite - (pressure rims). Watznaueria barnesae is abundant, Assipetra infracretacea, Calcicalathina oblongata, Cyclagelosphaera margerelii, Cruciellipsis cuvilieri, Cretarhabdus spp., Helenea chiastia, Rhagodiscus asper, Micrantholithus hoschulzii also occur - segments and many undeterminable heterococcoliths. Age: Valanginian-Early Barremian. 
ODG. Dark-grey, bioturbated, calcareouss claystone. Micritic calcite forms a minor componenet. The rock contains fragments of plant tissues, rarely pyritized and silicified ghosts of foraminifers. Fe-calcite rhombs are more common; pyrite is arranged as spots, or as larger aggregates. Some grains are formed by microcrystalline quartz. Watznaueria barnesae, Rucinolithus terebrodentarius, Litraphidites bollii, Calcicalathina oblongata, Conusphaera rothii, Cretarhabdus conicus, Micrantholithus hoschulzii - segments are present. Age: Late Hauterivian.

ODH. Dark-grey marly shale - calcareous marlstone (strongly reacts with $\mathrm{HCl}$ ). The matrix is represented by microcrystalline calcite. The rocks contains coalified plant tissue remnants, calcareous dinoflagellates Cadosinopsis nowaki, and non-calcareous ones - ?Hystrichosphaera, pyritized radiolarians replaced also by framboidal pyrite a ghosts of formainifers replaced by quartz. Silty detritic quartz is present, too, with considerable amount of mica scales. Assipetra infracretacea, Conusphaera rothii, Cyclagelosphaera margerelii, Cruciellipsis cuvilieri, Discorhabdus ignotus, Helenea chiastia, Litraphidites bollii, Rucinolithus terebrodentarius, segments of Micrantholithus hoschulzii, Watznaueria barnesae, Zeugrhabdotus embergeri are present. Age: Late Hauterivian.

ODI. Dark grey bioturbated calcareous marlstone. It contains calcareous dinoflagellates: Stomiosphaera sp., fragments of plant tissues, pyrite aggregates, clusters of framboidal pyrite, Fe-calcite rhombs, detritic silty quatz of various size and mica scales. Watznaueria barnesae is dominant, Cretarhabdus species, Tubodiscus spp.?, Retecapsa angustiforata, Rhagodiscus asper, Rucinolithus terebrodentarius, Nannoconus kamptneri kamptneri, Zeugrhabdotus diplogrammus, Z. embergeri are abundant. Age: Late Hauterivian.

ODJ. Dark-grey bioturbated calcareous marlstone. It contains silty quartz admixture, and also larger quartz grains. Abundant detritic quartz is concentrated by burrows of limnivores. Pyrite is abundant, rare is glauconite. Calcareous dinoflagellate cysts are poorly preserved, and some chitinous cysts. Watznaueria barnesae, Cretarhabdus conicus, Cyclagelosphaera margerelii, Retecapsa angustiforata, Rucinolithus terebrodentarius, Zeugrhabdotus diplogrammus, Z. embergeri are present. Age: Late Hauterivian.

ODK. Dark-grey bioturbated calcareous marlstone. A burrow filled with pyrite and calcite. The rock contains calcareous dinocysts Stomiosphaera echinata - glauconite grains, zircon. Watznaueria barnesae is dominant. Conusphaera rothii, Litraphidites bollii, Retecapsa angustiforata, Rucinolithus terebrodentarius, Zeugrhabdotus embergeri are present. Age: Late Hauterivian.

ODL. Dark-grey marlstone. It is bioturbated. Micrite is abundant. Silty angular quartz, mica scales, pyrite locally forming clusters and rare are Fe-calcite (or dolomite) rhombs are present. Yellowish-brown aggregates (probably chlorite) are common. Coalified fragments of plant tissues and pollen grains are present, too. Watznaueriaceae is dominant. Rucinolithus terebrodentarius is abundant; also present are Assipetra infracretacea, Cretarhabdus conicus, Cruciellipsis cuvilieri, Litraphidites bollii, Rhagodiscus asper, Speetonia colligata, Tubodiscus jurapelagicus, Zeugrhabdotus embergeri. Age: Late Hauterivian.

ODM 1. Dark-grey calcareous claystone. The matrix is formed by microcrystalline calcite and clay. It contains rare tests of tiny nodosariid foraminifers. Fine silty quartz, muscovite scales, clusters of pyrite, tiny Fe-calcite rhombs, tiny authigenic tourmaline grains and tiny fragments of plant tissues are present, too. Dominance of Watznaueriaceae was noted. Watznaueria manivitae, Cretarhabdus conicus, Litraphidites bollii, Retecapsa angustiforata, Rucinolithus terebrodentarius, Rucinolithus windleye, Staurolithites crux, Zeugrhabdotus embergeri are present. Age: Late Hauterivian.

ODM 2. Dark-grey calcareous claystone. The matrix is formed by microcrystalline calcite and clay minerals. It contains rare tests of tiny nodosariid foraminifers. Fine silty quartz, muscovite scales, clusters of pyrite, tiny Fe-calcite rhombs, tiny authigenic tourmaline grains and tiny fragments of plant tissues are present. Also fragments of silicites, pollen grains and fractured pyrite aggregates were observed.

ODN. Dark-grey marlstone. Pollen grains, fragments of plant tissues, silty quartz, pyrite aggregates, Fe-calcite rhombs, muscovite aggregates are present. Watznaueria barnesae dominates. Cretarhabdus conicus, Diazomatholithus lehmanii, Discorhabdus ignotus, Helenea chiastia, Litraphidites bollii, Retecapsa angustiforata, Rucinolithus terebrodentarius, $R$. windleye, Speetonia colligata, Zeugrhabdotus embergeri are present. Age: Late Hauterivian.

ODO. Calcareous siltstone with burrows filled with quartz grains. The quartz grains are from 0.1 to $0.8 \mathrm{~mm}$ in size. Foraminifers, crinoids, ghost of radiolarians, Stomiosphaera echinata, Cadosina semiradiata olzae, Colomisphaera conferta, Colomisphaera lucida are rare. Pyrite aggregates are dispersed in the matrix. Zircon also occurs in trace amounts, feldspars, staurolite, chlorite, rutile, glauconite, chessboard-like albite and silicite fragments. Watznaueria barnesae is dominant. Conusphaera rothii, Cretarhabdus conicus, Crucibiscutum salebrosum, Cyclagelosphaera margerelii, Diazomatholithus lehmannii, Helenea chiastia, Micrantholithus hoschulzii, Micrantholithus spp., Rhagodiscus asper, Rucinolithus terebrodentarius, Tegulalithus septentrionalis, Zeugrhabdotus scutula? are present. Rare nannoconnids - Nannoconus abundans?, N. inornatus?, N. spp. occur which together with Crucibiscutum salebrosum, Tegulalithus septentrionalis indicate boreal influence. Age: Late Hauterivian.

\section{Veřovice Formation}

ODP. Claystone. Rare is silty quartz, rhombs of calcite or siderite (about $0.03 \mathrm{~mm}$ in size), pyrite aggregates. Very fine coalified plant tissues fragments, pyritized radiolarian tests also are present. Foraminiferal tests are silicified. Sediment is bioturbated, showing as brown spots.

\section{Upper part of Hradiště Formation}

ODR. Claystone, almost free of carbonate. Rare tiny rhombs belong most likely to dolomite. Hydrosilicates (most probably illite) dominate, scarce is silty quartz, pyrite forming clusters, very fine coalified detritus of plant tissues, and Fe-hydroxides are present. 


\section{Thin sections}

OV 1-OV 3. Pelagic micritic limestones consisting of nannomicrite (recrystalized nannos). Nannofossils are occasionally preserved. Poorly preserved pelagic foraminifera, calcite replaced radiolarians (1-3\%), rare spicules and poorly preserved calcisphaeres occur in trace amounts.

OV 6. Calcite cemented fine-grained sandstone. It is moderately sorted, with grains subangular in shape. Some quartz grains are angular. Plutonic quartz is dominant, metamorphic quartz is minor. Glauconite occurs in traces, K-feldspar 1\%, perthitic orthoclase (trace). Bioclasts present $(0.5 \%)$ are represented by planctic foraminifera, sponge spicules, and thick wall shell debris of mollusks. Cement is void filling sparry calcite.

OV 8. Calcite cemented fine grained sandstone. It is bimodal in composition, comprised by fine sand grain-size particles $(0.14 \mathrm{~mm})$, mixed with coarse sand grains $(0.7-1.3 \mathrm{~mm})$. Quartz origin is $-2 / 3$ plutonic quartz, and 1/3 metamorphic. Fine grain size fraction is moderately sorted, grains are moderately rounded. In coarse fraction grains are subrounded. Feldspars are dominated by perthic K-feldspar (3-5\%). Mica and pyrite occur in traces. Calcite cement - is void filling (30\%). Bioclasts - echinoid spines, mollusk shell fragments, holothurian spiculae occur in trace amounts.

OTV 1-OTV 3. Pelagic limestone composed by nannomicrite with some nannos still recognizable. Radiolaria 3-5\%, are replaced by sparry calcite, few poorly preserved calcisphaerulids, traces of ostracoda shell and sponge spicules are present. Minor component consist of silt-size quartz and 7-10\% of silt size unidentifiable skeletal debris, suggesting either extensive burrowing or reworking and transportation of the material.

OTV 4. Gravelitic sandstone with limestone intraclasts and marly matrix. Grains are up to $4 \mathrm{~mm}$ in diameter, well rounded, but poorly sorted. Quartz from $80 \%$ is of plutonic origin, $20 \%$ is of metamorphic origin. Feldspars - traces of K-feldspar and perthitic orthoclase. Intraclasts are comprised of rounded pebbles of a limestone up to $7 \mathrm{~mm}$ in size, comprised by skeletal grainstone with thick-wall mollusk shell debris, micritized algae, and pelleted packestone. Few small foraminifera, blue-green algal crust debris, and debris of a hydrozoan are enclosed in some of the clasts.

OSV 1-OSV 2. Pelagic limestones with $1 \%$ of calcite replaced radiolarians and several recognizable nannofossils. Spicules are rare. OSV 7-OSV 9. Calcite cemented sandstones.

OSV 7. Medium grain-size sandstone. Quartz grains are moderately sorted, subangular in shape.

OSV 8. Coarse grained sandstone, grains are well sorted and well rounded.

OSV 9. Fine grained sandstone, grains are well sorted, well rounded with strong silica overgrowth; grains are stained by organic carbon (probably migrated hydrocarbons along microstylolite seems).

In all sandstones (OSV 7-9) K-feldspar is present > 5\%, which is variable altered (weathered). Bioclasts - trace amount to $2 \%$; sand size fragments of micritic limestone, mollusk shell fragments, peloids, benthic foraminifera, echinoid debris and calcareous algae (trace). Cement is void filling, coarse sparry calcite (late diagenetic cement). In sample OSV 8 patches of peculiar carbonate cement occur - it could be either pseudomorphs after aragonite splays, or it is bacterial origin (same carbonate occur in sample OTV 3). Lack of plagioclases is interesting between feldspar - may it suggest intensive chemical weathering?

OSV 10. Laminated sandstone, medium grain size; enclosing large fragments of ?dasycladacean algae. Algae are enclosed by coarser sand grains, which are poorly sorted, subangular. Sandstone is calcite cemented. Within algal debris are trapped debris of thick wall mollusk shell, echinoids, and a fish bones.

OR 1. Terrigenous sandstone with gravel size limestone intraclasts. Sandstone is cemented by carbonate with few patches of marl (sample similar to OTV 4). Sandstone is bimodal with gravel size grains (2-3\%) dispersed in finer sand. Quartz grains are medium-sized, moderately rounded and poorly sorted. Metaquartzite (2-3\%) and limestone intraclast - up to $4 \mathrm{~mm}$ in diameter (1-2\%) are the other sandstone component. Limestone intraclasts are of variable composition. Clasts of micritic limestone enclosing several poorly preserved calpionellids (?Tithonian); peloid packestone, fragment of ?biohermal limestone, mollusk shell fragments and echinoid debris (traces) are present. Between clastic grains several patches of marlstone with few recognizable nannofossils occur. Sandstone is cemented by carbonate, with the texture resembling either replacement of the aragonite, or being of bacterial origin. Fibrous calcite precipitated in a tectonic shadow as a rim on some of grain surfaces is also present. In the cement some of the crystal boundaries are stained by Corg, suggesting migration of hydrocarbons. 